\title{
Literature Review of Market Studies of Thermal Energy Storage
}

M. P. Hattrup

February 1988

Prepared for the U.S. Department of Energy under Contract DE-AC06-76RLO 1830

Pacific Northwest Laboratory Operated for the U.S. Department of Energy by Battelle Memorial Institute 


\title{
DISCLAIMER
}

This report was prepared as an account of work sponsored by an agency of the United States Government. Neither the United States Government nor any agency thereof, nor Battelle Memorial Institute, nor any or their employees, makes any warranty, expressed or implied, or assumes any legal liability or responsibility for the accuracy, completeness, or usefulness of any information, apparatus, product, or process disclosed, or represents that its use would not infringe privately owned rights. Reference herein to any specific commercial product, process, or service by trade name, trademark, manufacturer, or otherwise does not necessarily constitute or imply its endorsement, recommendation, or favoring by the United States Government or any agency thereof, or Battelle Memorial Institute. The views and opinions of authors expressed herein do not necessarily state or reflect those of the United States Government or any agency thereof, or Battelle Memorial Institute.

\author{
PACIFIC NORTHWEST LABORATORY \\ operated by \\ BATTELLE MEMORIAL INSTITUTE \\ for the \\ UNITED STATES DEPARTMENT OF ENERGY \\ under Contract DE-AC06-76RLO 1830
}

\begin{tabular}{|c|c|}
\hline \multicolumn{2}{|c|}{ Printed in the United States of America } \\
\hline \multirow{2}{*}{\multicolumn{2}{|c|}{$\begin{array}{l}\text { Available from } \\
\text { National Technical Information Service }\end{array}$}} \\
\hline & \\
\hline \multicolumn{2}{|c|}{ United States Department of Commerce } \\
\hline \multicolumn{2}{|c|}{$\begin{array}{c}5285 \text { Port Royal Road } \\
\text { Springfield, Virginia } 22161\end{array}$} \\
\hline \multirow{2}{*}{\multicolumn{2}{|c|}{$\begin{array}{l}\text { NTIS Price Codes } \\
\text { Microfiche A01 }\end{array}$}} \\
\hline & \\
\hline \multicolumn{2}{|c|}{ Printed Copy } \\
\hline & Price \\
\hline Pages & Codes \\
\hline $001-025$ & A02 \\
\hline 026-050 & $\mathrm{A} 03$ \\
\hline 051-075 & A04 \\
\hline 076-100 & A05 \\
\hline 101-125 & A06 \\
\hline $126-150$ & A07 \\
\hline $151-175$ & $\mathrm{~A} 0 \mathrm{~B}$ \\
\hline $176-200$ & A09 \\
\hline $201-225$ & A010 \\
\hline $226-250$ & A011 \\
\hline $251-275$ & A012 \\
\hline $276-300$ & $A 013$ \\
\hline
\end{tabular}


M. P. Hattrup

February 1988

Prepared for

the U.S. Department of Energy

under Contract DE-ACO6-76RL0 1830

Pacific Northwest Laboratory

Richland, Washington 99352 


\section{SUMMARY}

Pacific Northwest Laboratory (PNL) conducted a literature review to consolidate the findings of existing thermal energy storage (TES) market studies in the industrial, commercial, and residential sectors. The purpose of the project was to use the information to identify additional research needs within each of those market sectors and to provide direction for future technology transfer planning activities. The following major conclusions and recommendations are proposed from this study.

\section{INDUSTRIAL SECTOR}

- The literature review indicated that energy savings and energy displacement are two different criteria for evaluating TES potential and must be treated separately. The differences between the studies funded by the Electric Power Research Institute (EPRI) and the U.S. Department of Energy (DOE) show that each set of criteria can result in the selection of different industries and applications for TES technology. Currently in all three sectors, most TES applications are intended for energy displacement, although TES has an equally important energy-saving role.

- An analysis of the potential barriers to the transfer of high-temperature composite phase change media technology to the brick/ceramic industry is an appropriate next step for market research. This analysis should involve interviews or discussions with the brick manufacturing industry and potential manufacturers and suppliers of this technology to understand factors influencing the technology's successful commercialization.

- Research should be conducted to identify other industrial applications for the TES technology that are about to be demonstrated in the brick/ ceramic industry. Such research should focus on identifying industrial processes that generate high-temperature gaseous waste streams with time variant energy usage. Exogenous market factors should also be examined and considered in estimating potential energy savings. 
COMMERCIAL SECTOR

- A concept's success often requires a motivated constituency. Cool storage TES was introduced in the commercial sector largely because of aggressive support by EPRI and individual utilities. A motivated and financially sophisticated supporter of electric load displacement overcame the difficulties of marketing to a conservative, first-cost-sensitive sector.

- EPRI has been a prime mover of TES in the commercial sector because the technology has the potential to shift peak loads and enhance load factors. EPRI's primary TES research work will probably continue to be directed more toward peak shaving or displacement rather than energy conservation. Therefore, the DOE should direct future studies in areas of the commercial sector where energy savings are more important than energy displacement.

- TES market penetration in the commercial sector has been mainly in buildings with large central HVAC systems. Small package air conditioning units have notably different characteristics and should also be studied.

\section{RESIDENTIAL SECTOR}

- The market studies conducted to date indicate a large potential for energy displacement in the residential sector, but this sector may be difficult to penetrate. Previous studies indicate site-specific variability in occupant behavior as being a particularly difficult issue.

- Previous studies have given widely varying viewpoints regarding the market potential of cold storage TES in the residential market. Market penetration issues have seldom been investigated, and past attempts at estimating penetration have yielded fairly subjective estimates.

- The intermediates (i.e., architects/ engineers, builders, building code officials, etc.) with potential "veto" power over the successful transfer of the cool storage technology should be analyzed to help in new product concept development and design.

- A comparison of market penetration estimates for residential cool storage using several existing forecasting techniques might yield an estimate that is less subjective than the current estimates. 


\section{TABLE OF CONTENTS}

SUMMARY. . . ........................ ... i ...

INDUSTRIAL SECTOR ..................

COMMERCIAL SECTOR .................... iv

RESIDENTIAL SECTOR. ................. iv

1.0 INTRODUCTION. . . . . . . . . . . . . . . . . . 1

1.1 BACKGROUND .......................... 1

1.2 METHODOLOGY. . . . . . . . . . . . . . . 1

1.3 ORGANIZATION OF THE REPORT ................ 2

2.0 A CHRONOLOGY OF TES MARKET ASSESSMENTS. . . . . . . . . . . 3

2.1 STUdIES COMPLETED DURING THE 1970 's.......... 3

2.1.1 The First Study of Thermal Electric Storage . . . . 3

2.1.2 Other Studies Completed During the 1970's . . . . 5

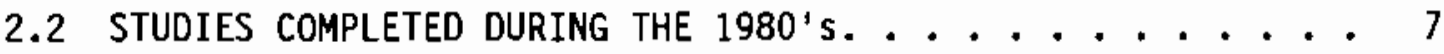

2.2.1 First Major Market Assessment of the 1980's . . . . 7

2.2.2 Studies Completed in 1983 and 1984. . . . . . . 10

2.2.3 Recent Literature............... 11

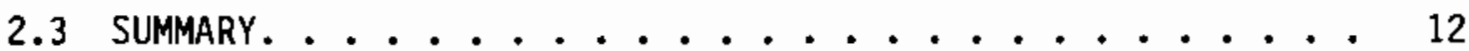

3.0 MARKET ASSESSMENTS IN THE INDUSTRIAL SECTOR. . . . . . . . 13

3.1 INDUSTRY SELECTION CRITERIA. . . . . . . . . . 13

3.2 MARKET ASSESSMENTS BY THE DOE. . . . . . . . . . . . 13

3.2.1 DOE's Preliminary Selection Criteria. . . . . . . 14

3.2.2 Predicted Impact of TES by 1985 vs. Current Status. - 16

3.3 MARKET ASSESSMENTS BY EPRI . . . . . . . . . . . . 17

3.3.1 EPRI's Preliminary Selection Criteria . . . . . . 17

3.3.2 Findings of the First EPRI Study. . . . . . . . . 18 
3.3.3 Impact of the 1982 Report's Conclusions on the 1984 Report .............. 19

3.4 OTHER STUDIES CONCERNING TES IN THE INDUSTRIAL SECTOR. . . 20

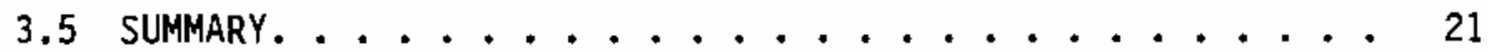

4.0 MARKET ASSESSMENTS IN THE RESIDENTIAL AND COMMERCIAL SECTORS. . . 23

4.1 THE MARXET POTENTIAL OF TES IN THE RESIDENTIAL AND

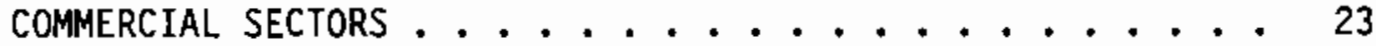

4.2 FINDINGS OF RESIDENTIAL AND COMMERCIAL MARKET ASSESSMENTS. • 24

4.2.1 First Major TES Report on the Residential and Commercial Sectors. ............. 24

4.2.2 Field Tests by Universities and Utilities . . . . 25

4.2.3 The Role of the Utility in Fostering TES. . . . . 27

4.2.4 EPRI's Most Recent Studies. . . . . . . . . 28

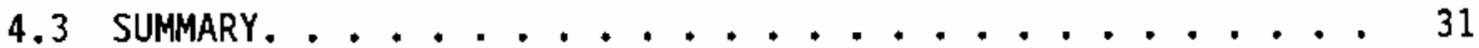

REFERENCES ........................ 33

APPENDIX - ANNOTATED BIBLIOGRAPHY. .............. A.1 


\subsection{INTRODUCTION}

This report presents the results of a review of market studies of themal energy storage (TES). This project was conducted by Pacific Northwest Laboratory (PNL) for the U.S. Department of Energy (DOE). PNL staff reviewed and consolidated the findings of existing TES market studies conducted in the industrial, commercial, and residential sectors. The purpose of this project was to review and assess previous work and to use the infomation obtained to help provide direction for future technology transfer planning activities and to identify additional economic research needed within those three sectors.

\subsection{BACKGROUND}

Thermal energy storage allows heat (or chill) to be captured and retained during one period for use during another period. When TES is applied to building heating and cooling, it allows efficient use of energy from such diverse sources as solar-themal collectors, industrial waste streams, utility and industrial cogeneration facilities, and winter-chilled air. The use of these alternative energy sources supports the U.S. goal of saving energy by reducing dependence on fossil fuels.

Applying TES in industry can potentially save significant amounts of energy and displace fossil fuels because industrial energy use accounts for about $40 \%$ of the U.S.'s total energy demand. For the utility industry, TES also offers a low-cost alternative to meeting utility system peakloads by storing thermal energy during offpeak hours (usually late at night) for use during peak periods. This thermal energy may be stored at either the customer side (load leveling) or at the utility power plant (load following) (TRW 1979).

\subsection{METHODOLOGY}

To obtain infomation on TES market studies, a literature search was conducted using several energy-related computerized data bases that contain reports and articles. Reports and articles with pertinent titles or relevant information included in an abstract were tentatively identified as possible sources of information. That approach produced approximately 36 documents, 
which were then reviewed for specific information on TES applications. While an extensive literature review was conducted, it is possible that some relevant material either was not included in the data base or was missed by the data base search.

\subsection{ORGANIZATION OF THE REPORT}

It was immediately apparent from the literature review that the industrial sector is significantly different from the commercial and residential sectors. This difference among sectors sets up a natural organization for the report. Chapter 2.0 presents a chronology of the TES market assessments completed in the 1970's and the 1980's in all three sectors. That information should enable readers to see the progression of TES-related research in all sectors and give them a better understanding of the subsequent discussions. Chapter 3.0 reviews the TES market assessment studies involving the industrial sectors, and Chapter 4.0 reviews studies involving the residential and commercial sectors. The appendix contains an annotated bibliography that briefly describes each identified source of information. 


\subsection{A CHRONOLOGY OF TES MARKET ASSESSMENTS}

This chapter provides a chronological description of TES market assessments, starting with the 1970 's. The objective is to provide a historical perspective to various TES studies in the industrial, commercial, and residential sectors before each sector is examined individually.

\subsection{STUDIES COMPLETED DURING THE 1970's}

Table 2.1 sumarizes the chronology of studies completed during the 1970's and contains the following information for each document: publication date; the particular sector(s) (residential, commercial, industrial) discussed; the form of thermat energy stored (heat vs. cool); the sponsoring agency; and a short description of the contents.

In Section 2.1.1, the initial TES market study conducted by the Energy Research and Development Administration (ERDA) is described. This study is significant because, to a great extent, it set the research agenda for the rest of the decade. Section 2.1.2 decribes the remaining studies conducted during the 1970's.

\subsubsection{The First Study of Thermal Electric Storage}

The first study of TES was commissioned by ERDA and was undertaken by General Electric in 1976 (Glenn 1976a). The study constituted the first major study of the economic and technical feasibility of TES. It was a cross-cutting study in that it encompassed the residential, commercial and industrial sectors and contributed to the overall ERDA objective of establishing priorities for developing and disseminating TES technology on a national basis. To attain ERDA's objective, the following analyses were undertaken as part of the study:

- analysis of energy usage throughout the residential, commercial and industrial sectors

- analysis of energy distribution by end use within the residential, commercial and industrial sectors 
TABLE 2.1. A Chronology of Thermal Energy Storage Market Assessment Studies of the 1970s

\begin{tabular}{|c|c|c|c|c|c|}
\hline & $\begin{array}{l}\text { Year } \\
\text { Published }\end{array}$ & Sectors (a) & $\begin{array}{l}\text { Storage } \\
\text { Type(b) }\end{array}$ & Sponsor & Description \\
\hline & 1976 & $I-R-C$ & $\mathrm{H}-\mathrm{C}$ & ERDA & Technical and economic feasibility of TES (Glenn 1976a) \\
\hline & 1976 & 1 & H & ERDA & $\begin{array}{l}\text { TES application to the brick/ceramic industry (Glenn } \\
1976 \text { b) }\end{array}$ \\
\hline & 1978 & I & H & DOE & $\begin{array}{l}\text { TES applications to process heat storage and recov- } \\
\text { ery in the paper and pulp industry (Carr, Hurley and } \\
\text { Martin 1978) }\end{array}$ \\
\hline & 1978 & I & H & DOE & $\begin{array}{l}\text { TES applications in the cement industry (Jaeger } \\
\text { et al. 1978) }\end{array}$ \\
\hline$\oplus$ & 1978 & I & H & DOE & $\begin{array}{l}\text { TES applications to process heat and waste heat } \\
\text { recovery in the iron and steel industry (Katter and } \\
\text { Peterson 1978) }\end{array}$ \\
\hline & 1979 & I & H & DOE & $\begin{array}{l}\text { TES applications to process heat and waste heat } \\
\text { recovery in the primary aluminum industry (Katter and } \\
\text { Hoskins 1979) }\end{array}$ \\
\hline & 1979 & 1 & H & $\mathrm{DOE}$ & $\begin{array}{l}\text { TES applications to waste heat recovery in the food } \\
\text { processing industry (Lundberg and Christenson 1979) }\end{array}$ \\
\hline & 1979 & $I-R-C$ & $\mathrm{H}-\mathrm{C}$ & DOE & TES application areas (TRW 1979) \\
\hline & 1979 & 1 & H & $\begin{array}{l}\text { Pacific Northwest } \\
\text { Governors } \\
\text { Commission }\end{array}$ & $\begin{array}{l}\text { Industrial waste heat for commity applications (Smith } \\
\text { and Huxtable 1979) }\end{array}$ \\
\hline
\end{tabular}

(a) 1 = lndustrial, $R=$ Residential, $C=$ Commercial.

(b) $\mathrm{H}=$ Heat, $\mathrm{C}=\mathrm{CoO}$ 
- summary of the technology status of TES-related research and development

- definition of barriers and economic considerations in implementing TES

- recognition and synthesis of TES applications.

These analyses were undertaken using a current energy scenario (i.e., current use, supply, demand, and price in 1976) and a future energy scenario (i.e., predicted use, supply, demand, and price for the early 1980's).

of the five analyses outlined above, the analysis of barriers within the sectors may have had the most impact on government research. That analysis identified the industrial sector as being the most receptive environment for disseminating TES technology. It was determined that, because the decision makers in the residential and commercial sectors tend to resist change in general and are very first-cost sensitive. TES would not get strong support and would be adopted slowly. The industrial sector was not expected to have that reaction because the decision makers in this sector understand and appreciate life-cycle costing and would be the first sector to suffer an impact if the energy supply decreased. Therefore, industry was expected to be more receptive to developing and using TES. This information on TES's potential use or adoption in the various sectors helps explain the subsequent focusing of government-funded research on the industrial rather than on residential and commercial sectors.

\subsubsection{Other Studies Completed During the 1970's}

The research emphasis on industrial applications as a result of the General Electric study (Glenn 1976a) explains the early predominance in the TES literature of reports dealing with TES applications for the industrial sector. While the residential and commercial sectors were not completely ignored, research on those sectors was not emphasized. Following the General Electric study in early 1976, eight reports were published by 1979, each containing some information regarding application of TES to industry.

The first of these reports was published in 1976 and assessed energy use within the brick and ceramic industry (Glenn 1976b). That study was funded by 
ERDA as a direct extension of the earlier cross-cutting effort (Glenn 1976a) in which the brick/ceramic industry had been identified as a potential consumer of the TES technology.

By 1979 five more DOE funded reports were published--each can be attributed to the recominendations made in the original cross-cutting study (Glenn 1976a). Three of the reports were available by 1978, covering the iron and steel (Katter and Peterson 1978), cement (Jaeger et al. 1978), and paper and pulp (Carr, Hurley and Martin 1978) industries. In 1979 the last two studies, on the food processing and aluminum industries, were published (Lundberg and Christenson 1979; Katter and Hoskins 1979). All five industries had been identified in the cross-cutting effort (Glenn 1976a) as high potential areas for TES applications.

Two other studies were reported in 1979 and include a report written by TRW (1979) for DOE and a paper presented at the Sixth Energy Technology Conference (Smith and Huxtable 1979). The TRW report reviewed TES technology and potential in each of the following areas:

- seasonal storage for building heating and cooling (i.e.., aquifer storage)

- thermal storage for industrial waste and process heat recovery

- thermal storage for solar-thermal power generation

- dally and short-term storage for buflding heating and cooling, and thermal storage for electric utility load management (TRW 1979).

The TRW report also provided an "overview" of five of the six individual industry studies that had been published in the previous two years.

The paper presented at the Sixth Energy Technology Conference discussed the results of a program sponsored by the Pacific Northwest Regional Commission, representing the Governors of Oregon, Washington, Idaho, and the U.S Department of Commerce (Smith and Huxtable 1979). The goal of the program was to document the potential use of industrial waste heat in the northwest region. This particular study looked at the potential for relatively low-temperature applications in an area surrounding a plant. Those applications would consist primarily of district heating systems. 


\subsection{STUDIES COMPLETED DURING THE 1980's}

Table 2.2 summarizes the chronology of studies completed during the 1980 's and includes the following information for each document: publication date; the particular sector(s) (residential, commercial, industrial) discussed; the form of thermal energy stored (heat vs. cool); the sponsoring agency; and a short description of the contents. The studies are discussed in the following three subsections. One subsection discusses the initial market studies conducted in the 1980's; the second discusses several documents published in 1983 and 1984; and the final subsection discusses the most recent literature (1985 and 1986).

\subsubsection{First Major Market Assessments of the 1980's}

The literature review indicated that the first major market assessment studies of TES in the 1980's were published in 1982 and concerned the industrial sector. One was funded by the DOE and another was funded by EPRI.

The DOE project was a follow-up survey of the brick and ceramic industries and was conducted by the Institute of Gas Technology (IGT 1982). This report updated and expanded the results of the earlier investigation of the brick and ceramic industry (Glenn 1976b).

The EPRI study was documented in two volumes and examined TES potential in the industrial sector (McChesney et al. 1982a, 1982b). The study was conducted by United Technologies Research Center (UTRC) for EPRI. The McChesney study, similar to the previous government-funded studies, examined the potential for TES in industrial applications. However, the method for selecting industries for this EPRI study was different from previous studies. Most of the previous market assessment studies done for the government included industries that were selected because they were known to have high national energy usage.

The approach used in the EPRI study consisted of screening all currently available industrial data to identify industries that have time-of-day energyuse variations that could benefit from TES. The intent of this method was to identify industries that were prime targets for shifting electric energy usage to off-peak times. This approach resulted in the analysis of a wide variety 
TABLE 2.2. A Chronology of Thermal Energy Storage Market Assessment Studies of the 1980s

\begin{tabular}{|c|c|c|c|c|}
\hline $\begin{array}{c}\text { Year } \\
\text { Published } \\
\end{array}$ & Sectors (a) & $\begin{array}{l}\text { Storage } \\
\text { Type }(5)\end{array}$ & Sponsor & Description \\
\hline 1982 & $\mathrm{I}$ & $\mathrm{H}$ & EPRI & $\begin{array}{l}\text { Evaluation of industrial advanced heat recovery/thermal } \\
\text { energy storage (McChesney et al. 1982a, 1982b) }\end{array}$ \\
\hline 1982 & I & $H$ & DOE & $\begin{array}{l}\text { TES system definition study and industry characteriza- } \\
\text { tion for the brick, clay and ceramic industry (Insti- } \\
\text { tute of Gas Technology 1982) }\end{array}$ \\
\hline 1983 & $\mathrm{R}-\mathrm{C}$ & $\mathrm{H}-\mathrm{C}$ & EPRI & $\begin{array}{l}\text { Opportunities in TES R\&D for the residential and commer- } \\
\text { cial sectors (Electric Power Research Institute 1983) }\end{array}$ \\
\hline $\begin{array}{l}1983 \\
1984\end{array}$ & $\mathrm{R}$ & H & $\mathrm{DOE}$ & $\begin{array}{l}\text { Thermal storage field test for residential heating units } \\
\text { (Hersh 1983) }\end{array}$ \\
\hline 1984 & $\mathbf{R}$ & H & $\begin{array}{l}\text { Amer. Electric } \\
\text { Power }\end{array}$ & $\begin{array}{l}\text { Thermal storage--tomorrow's heat today--field test of } \\
\text { residential heating units (Coleman 1984) }\end{array}$ \\
\hline 1984 & I & H & EPRI & $\begin{array}{l}\text { Identification of TES opportunities in industrial } \\
\text { processes (Melikian, McChesney and 0bee 1984) }\end{array}$ \\
\hline 1984 & I & H & EPRI-DOE & $\begin{array}{l}\text { Assessment of nonlatent heat storage technologies for } \\
\text { industrial applications (Melikian and McChesney 1984) }\end{array}$ \\
\hline 1985 & $I-C$ & H & olin Corp. & $\begin{array}{l}\text { High temperature energy storage--what lies ahead } \\
\text { (Christopher 1985) }\end{array}$ \\
\hline 1985 & C & C & EPRI & Current trends in commercial cool storage (Hersh 1985) \\
\hline 1985 & $\mathrm{R}-\mathrm{C}$ & C & $\begin{array}{l}\text { International } \\
\text { TES Advisory } \\
\text { Council }\end{array}$ & $\begin{array}{l}\text { The strong case for thermal energy storage and utility } \\
\text { incentives (McCannon 1985) }\end{array}$ \\
\hline
\end{tabular}


TABLE 2.2. (contd)

Year

Published Sectors(a) Storage

1985

C

c

Sponsor

Description

Survey of commercial sector demand-side management (DSM) activities (Sloane 1985)

$1986 \quad$ I $\quad H \quad$ DOE

High temperature composite TES systems for industrial applications (Petri and 0ng 1986)

Market constraints for residential cool storage systems (Ashbury 1986)

$\omega$

$\begin{array}{llll}1986 & R & C & \text { EPRI }\end{array}$

1986

R-C

EPRI

1986

$\mathbf{R}$

$\mathrm{H}-\mathrm{C}$

EPRI

Market assessment of heat storage systems in residen$t i a l$ and commercial buildings [see (a) on p. 30]

1985 survey of utility residential end-use projects (Belvins et al. 1986)

(a) $I=$ Industrial, $\mathrm{R}=$ Residential, $\mathrm{C}=$ Commercial.

(b) $\mathrm{H}=$ Heat, $\mathrm{C}=\mathrm{Cool}$.

(c) Bernstein, S., B. Hyman and R. Kunkle. July 1986 (Informal Report). Market Assessment of Heat Storage Systems in Residential and Commercial Buildings. Prepared by Energy International, Inc., for the Electric Power Research Institute. 
of industries in a single study (McChesney et al. 1982a, 1982b) and in the selection of different industries from those selected in DOE's industrial studies.

Both selection processes have advantages, and several industries were selected both by the EPRI selection criteria and by the criteria from earlier DOE studies, but the difference was important because of the substantial impact on the overall selection process. Beyond the initial selection of candidate industries, the DOE and EPRI study approaches are similar. Chapter 3.0 will discuss the different selection criteria used by the DOE and EPRI.

\subsubsection{Studies Completed in 1983 and 1984}

The next study dealing with the potential for TES was published by EPRI in 1983 (EPRI 1983) and dealt exclusively with applications in the residential and commercial sectors. This was the first comprehensive report on the residential and commercial sectors to be identified by this literature review.

This study involved panel discussions by experts to evaluate a number of promising improvements in TES materials, heat exchange technology, thermal insulation, and controls. These discussions took place at two EPRI-sponsored workshops on heat and cool storage. About 40 representatives from the $D O E, D O E$ laboratories, universities, private industry, and utilities participated in the workshops.

The literature review revealed other documents concerning applications of TES in the residential or commercial sectors. One typical document was a paper concerning TES applications in the residential sector (Hersh 1983). The paper reported the results of a field test of TES equipment used for heating residences. The paper also discussed, in very general terms, the potential for application of such equipment in the U.S. housing stock.

In 1984 one residential study and two industrial market assessments for TES were published. The study of the residential sector was quite similar to Hersh (1983) because it also involved a field test of TES equipment used for heating residences and for providing domestic hot water (Coleman 1984). This study was sponsored by the American Electric Power (AEP) Service Corpor- 
ation and took place in five states (Virginia, West Virginia, Ohio, Indiana, and Michigan).

The two documents published in 1984 assessing TES potential for the industrial sector were papers, one discussing a new study and the other presenting information from a previous study. The new study was a direct extension of an ongoing EPRI-funded program to assist member utilities in identifying and evaluating industrial process energy conservation and management opportunities (Melikian, McChesney and Obee 1984). This study was undertaken by UTRC, the same firm which conducted the earlier EPRI-sponsored industrial sector analysis (McChesney 1982a, 1982b). The second paper summarized the results of McChesney et al. and was presented at the International Energy Agency Workshop on Latent Heat Stores in Stutgart, FRG, in March of 1984 (Melikian and McChesney 1984).

\subsubsection{Recent Literature}

In 1985 four documents were published which discussed various aspects of TES applications in both the industrial and commercial sectors. In a paper, Christopher (1985) discussed the potential uses of high-temperature TES. He gave potential market figures and described various potential benefits of different technologies. Sloane (1985) examined various utility activities for commercial-sector demand side management (DSM). A part of sloane's report discussed utility experiences with TES applications for space heating/water heating, cool storage and combination heat and cool storage. Reports by Hersh (1985) and McCannon (1985) discussed the status and potential of commercial "cool" storage technology. At the 12th Energy Technology Conference, McCannon (1985) presented a report on cool storage and discussed issues that must be addressed to increase the potential for cool storage.

In 1986 EPRI produced three publications dealing with TES potential in the residential and commercial sectors. One study (Asbury 1986) looked at the constraints that cool storage faces in the residential market. Another study (a)

(a) Bernstein, S, B. Hyman and R. Kunkle. July 1986 (Informal Report). Market Assessment of Heat Storage Systems in Residential and Commercial Buildings. Prepared by Energy International, Inc., for the Electric Power Research Institute, Palo Alto, California. 
assessed the market for heat storage systems in both the residential and commerclal sectors. The third report (Blevins et al. 1986) examined the utility industries' DSM activities aimed at the residential sector.

The industrial sector also received attention in 1986; a paper presented at the 21st Intersociety Energy Conversion Engineering Conference discussed the composite phase change material concept to be used in industrial applications (Petri and Ong 1986).

\subsection{SUMMARY}

A review of the chronology of TES market assessments shows that the industrial sector was the initial focus of attempts to identify applications of TES technology. It wasn't until 1983 that a major report dedicated to the residential and commercial sectors was published by EPRI; this report discussed market issues as well as other issues (earlier reports seldom discussed market issues). Since 1983 the residential and commercial sectors have received increased research attention. 


\subsection{MARKET ASSESSMENTS IN THE INDUSTRIAL SECTOR}

This chapter discusses the results of the literature review of market assessments in the industrial sector. Section 3.1 presents a brief overview of the criteria used by the DOE and EPRI to select the industries for their studies. Sections 3.2 and 3.3 discuss individually the selection criteria used for DOE-funded and EPRI-funded market assessment studies, respectively, and the findings of those studies. Section 3.4 discusses non-DOE and nonEPRI studies that address other general aspects of the industrial market potential for TES.

\subsection{INDUSTRY SELECTION CRITERIA}

The industries selected as top candidates for the industrial market assessment studies depend, to some extent, on the criteria used by the sponsoring organization in screening industries. Table 3.1 summarizes the primary criteria for industry selection used in three different studies that assessed the industrial sector. The two earlier studies placed primary emphasis on the energy consumption of an industry relative to other industrfes (Glenn 1976a; and McChesney et al. 1982a, 1982b). On the other hand, the last study focused more on individual plants that could be operated more efficiently and that had time-variant energy processes that could benefit from TES (Melikian, McChesney and Obee 1984).

\subsection{MARKET ASSESSMENTS BY THE DOE}

The first market assessment/industry characterization studies were conducted as a result of the realization that the improvement of industrial energy efficiency was increasing in importance (Petri and Ong 1986). The first study to look at the application of TES in industry, referred to earlier as the cross-cutting study (Glenn 1976a), was a broad attempt to develop a structure that could help the government's effort to maximize the impact of its TESrelated research. A substantial part of that first report was involved with groundwork associated with selecting the industries that might best be 
TABLE 3.1. The Primary or Preliminary Selection Criteria Used in Studies to Select Candidate Industries for Detailed Analysis

Agency/Study Date

ERDA $/ 1976^{\text {(a) }}$

(Glenn 1976a)

EPRI $/ 1982^{(b)}$

(McChesney et al.

$1982 a, 1982 b)$
EPRI $/ 1984^{\text {(c) }}$

(Melikian, McChesney and Obee 1984)
Selection Criteria

1. Candidate industries must be substantial consumers of energy.

2. Their energy costs should be a significant part of total product cost.

3. They should have "standard" processes and procedures.

4. Their processes should have some form of cyclic interaction.

1. Candidate industries must be energy intensive where energy consumption is a significant cost factor, and they should have identifiable waste heat sources.

2. They should have batch-or shift-oriented processes, batch/continuous processes, or continuous processes with time-varying energy demands.

Candidate plants were selected by utilities if the plant expressed interest in assessing ways to operate more efficiently.

(a) This study's main criterion for industry selection was "total industry" energy consumption as defined by past energy consumption figures.

(b) This study's main underlying criterion was the location of processes with time-of-day energy-use variance.

(c) This study's criterion for candidate selection was "consumer interest" in assessing operating efficiencies ("customer service approach").

suited to TES applications. The following sections discuss DOE's preliminary selection criteria, and the predicted and current status of TES.

\subsubsection{DOE's Preliminary Selection Criteria}

The DOE's preliminary criteria used to select an industry were as follows:

- A candidate industry must be a substantial consumer of energy, with energy costs representing a substantial portion of the total product costs.

- The industry should have a well-defined product in which standard processes and methods are widely used. 
- Some form of cyclic interaction of the thermal production processes must occur that provides a possible application for TES (Glenn 1976a).

These criteria were used to select the six industries examined by DOE: brick and ceramic, paper and pulp, cement, iron and steel, aluminum, and food processing. A more detailed analys is of these industries in separate studies yielded estimates of market potential and market penetration (IGT 1982; Carr, Hurley and Martin 1978; Jaeger et al. 1978; Katter and Peterson 1978; Katter and Hoskins 1979; and Lundberg and Christenson 1979). The findings from those DOE-sponsored studies are listed in Table 3.2.

Table 3.2 shows that market potential and market penetration estimates from the DOE studies. Market potential is typically defined as the total number of consumers who might be able to use a new product or technology. In this case, market potential is specified as the total energy savings that can be expected if all the consumers who could use the technology do so. Market penetration, on the other hand, is typically an estimate of the number of

TABLE 3.2. Findings from DOE-Sponsored Industrial Market Assessment Studies

\begin{tabular}{|c|c|c|}
\hline Market & Estimated Market Potential (quad/yr) & $\begin{array}{l}\text { Estimated } \\
\text { Market Penetration }\end{array}$ \\
\hline Brick/Ceramic & $\begin{array}{l}0.016 \text { (Glenn 1976a) } \\
0.0427 \text { (IGT 1982) }\end{array}$ & $100 \%$ by $1980 \mathrm{~s}$ \\
\hline Paper and Pulp & $\begin{array}{l}0.017 \text { (TRW 1979) } \\
0.0186 \text { (Carr, Hurley and Martin } \\
1978 \text { ) }\end{array}$ & $\begin{array}{l}23 \% \text { by } 1985 \\
25 \% \text { by } 1980 \text { s }\end{array}$ \\
\hline Cement & $\begin{array}{l}0.041 \text { (TRW } 1979) \\
0.023 \text { to } .039 \text { (Jaeger et al. 1978) }\end{array}$ & $100 \%$ by 1985 \\
\hline Iron and Steel & $\begin{array}{l}0.006 \text { (TRW 1979) } \\
0.011 \text { (Katter and Peterson 1978) }\end{array}$ & $\begin{array}{l}100 \% \text { by } 1985 \\
100 \% \text { by } 1985\end{array}$ \\
\hline Aluminum & 0.0378 (Katter and Hoskins 1979) & $\begin{array}{l}31 \text { Plants or } 100 \% \\
\text { by } 1985 \\
1 \text { Plant by } 1985 \\
\text { (TRW 1979) }\end{array}$ \\
\hline Food Processing & $\begin{array}{l}0.006 \text { (TRW 1979) } \\
0.006 \text { (Lundberg and Christenson 1979) }\end{array}$ & $40 \%$ by 1985 \\
\hline
\end{tabular}


consumers who not only could use a new product or technology, but also are expected to do so.

Generally when penetration estimates were given in the six documents found in the literature review, those estimates were based on the assumption that the DOE and the private sector would invest substantial resources in implementation efforts. This was a reasonable assumption considering the unstable price of energy at that time. However, the assumption turned out to be incorrect. Also it appears that some of these estimates were arrived at with various degrees of subjective judgment. The combination of the incorrect assumption and the subjective Judgments tended to result in highly optimistic estimates of energy savings. The next section discusses the predicted impact vs. the current status of TES applications.

\subsubsection{Predicted Impact of TES by 1985 vs, Current Status}

The analysis of the six industries selected yielded a combined estimate of .11 quad as the potential annual energy savings achievable if TES were to be used on a nationwide basis (Carr, Hurley and Martin 1978; Jaeger et al. 1978; Katter and Peterson 1978; Katter and Hoskins 1979; Lundberg and Christenson 1979; and IGT 1982). All of the individual industry-specific estimates assumed a more rapid rate of adoption than occurred.

The combined .11 quad figure was derived simply by adding each industry's energy-savings estimates, which generally were based on the assumption that industrywide implementation would be complete by 1985 . However, the full-scale commercialization of the TES applications identified in these studies are currently at various stages of development. Therefore, none of these estimates have been substantiated by actual adoption behavior. For example, the paper and pulp industry has operational TES systems that have not yet been made public. Also, the TES applications in the food processing industry could use existing technology and equipment for system demonstration, but have yet to do so.

The TES applications in most industries are far from commercialization because additional technology development is required to achieve costeffective energy storage. The six industry studies identified in the literature 
review resulted in a program aimed at demonstrating first-generation hightemperature TES in the brick/ceramic industry. This program has undergone a subsequent redirection toward developing second generation advanced latent-sensible composite phase change media storage systems which offer improved economic and performance benefits (Petri and Ong 1986). The DOE is currently conducting a field test of this concept. Consequently, industry-wide utilization will be some years in the future.

\subsection{MARKET ASSESSMENTS BY EPRI}

Table 3.3 summarizes the findings of EPRI-sponsored industrial market assessment studies and contains the estimated market potential (i.e., energy savings) achievable by applying TES. Because the EPRI reports do not give a

timeframe for reaching the predicted market potential, no market penetration figures are included in the table. The following sections discuss EPRI's preliminary selection criteria and the findings of the first two EPRI reports identified in the literature review.

\subsubsection{EPRI's Preliminary Selection Criteria}

The criteria used by EPRI are somewhat different from those used by the DOE because its fundamental objectives are different. In 1982 EPRI contracted with UTRC to study the potential of TES for industrial applications; this

TABLE 3.3. Findings from EPRI-Sponsored Industrial Market Assessment Studies

\begin{tabular}{lc} 
Market & $\begin{array}{c}\text { Estimated } \\
\text { Market } \\
\text { Potential } \\
\left(10^{12} \text { Btu/yr }\right)\end{array}$ \\
\hline Fluid Milk & 0.05 \\
Canned Specialties & 0.02 \\
Synthetic Rubber & 2.7 \\
Steel Rolling Mill & 42.3 \\
Coke Plant & 68.4 \\
Farm Machinery & 0.10 \\
Aerospace Equipment & 0.05
\end{tabular}


study yielded two reports (McChesney et al. 1982a, 1982b). McChesney et al. used a slightly different selection method from that used in the previous DOE-funded studies. Most of the previous market assessment studies selected industries with high national energy usage, whereas this first EPRI study selected industries primarily on the basis of time-variant energy usage. EPRI later did a second study in which specific plants were selected on the basis of their expressed interest in increasing operating efficiencies (Melikian, McChesney and obee 1984). The findings of the first study are discussed in more detail in the following section.

\subsubsection{Findings of the First EPRI Study}

As already discussed, the first EPRI study located in this literature review was published in 1982 in two volumes (McChesney et al. 1982a, 1982b). The study estimated that the economic recovery (220x) of waste heat to generate process heat or electrical power could result in the displacement of fossit fuels equivalent to 0.38 quad. Note that this number greatly exceeds the combined estimated savings of 0.11 quad given in Table 3.3; the numbers differ because the 0.11 quad includes only the savings attributable to TES, whereas the 0.38 includes both TES and advanced heat recovery (AHR) technologies. Therefore, the 0.38 quad should be viewed only as an upper boundary for potential energy savings that could be achieved with AHR concepts, and to a lesser extent, TES.

The 0.38 quad figure was arrived at using a cross-correlation analysis, conducted to assess the extent to which AHR/TES applications identified in one plant would also apply to other plants within the same industry and in other industries having similar plant/process characteristics (McChesney 1982a, 1982b). The plant-specific results that were ultimately projected to a national basis with the cross-correlation analysis came from 24 system analyses at the plant level. This approach yields an upper bound on the industrial potential for TES. Even so, the author states that the estimate is a more realistic indicator of the useful recovery potential for industrial waste heat in general--either with or without TES (McChesney et al. 1982b). 
The report made the following conclusions from the results of the 24 plantlevel system analyses (McChesney et al. 1982a):

1. Large quantities of waste heat are available from the industrial plants within the United States, and results derived in this study have shown that, for selected applications, fuel energy savings can be enhanced and optimized using energy management systems that are TES-based and commercially available.

2. The results of this study have shown that TES systems, used with selected energy management equipment, can be economically justified to enhance system energy savings. However, because of the many technical and economic factors involved in designing and evaluating AHR/TES systems, the decision to proceed with a specific application will be closely related to the operating conditions and economic constraints of each potential site.

3. While any one application, by itself, may not represent a major impact on an electric utility, the aggregate of several AHR/TES installations within a specific service area could be of significance to that utility.

4. Fourteen sensible and latent TES system concepts were characterized as being commercially available by 1985 . However, the results of this investigation have shown that sensible energy storage will probably be the economic choice for most of those waste heat recovery applications requiring thermal storage.

\subsubsection{Impact of the 1982 Report's Conclusions on the 1984 Report}

As mentioned earlier, the next industrial-sector EPRI study identified by the literature was published in 1984 (Melikian, McChesney, and obee 1984). It was an extension of an ongoing EPRI-funded program to assist member utilities in identifying and evaluating the potential for TES in their industrial customer's plants and processes.

This study is unique in that it used onsite characterization similar to previous studies, but site selection was done by a local utility. National potential was never an issue in this site selection process because the industrial plants were selected by their supplying utilities, based on an expressed 
interest in operation assessment. This study did not estimate the potential of TES applications for a specific industry or for a group of industries, and is included in this report because of the novel approach. By not providing such estimates, the study indicates that the decision to install a TES system is so dependent on site-specific information, that an estimate of a national or industrywide savings' potential based on one plant's experience may be of little value (Melikian, McChesney and Obee 1984).

This approach to selecting individual candidate sites may have a significant effect on the "effectiveness" of the TES research in the industrial sector because it avoids one of the admitted shortcomings of the previous approach of generic industry selection. The shortcoming of generic industry selection and analysis is that optimal selection of a TES system depends on the individual plant's operating characteristics; therefore, it is unlikely that a plant manager would view a generic industry study as a good tool to use in making an investment decision regarding TES. The site-specific approach used in this study may be more successful in encouraging field demonstrations because the key site-specific factors have been included in the evaluation of technical and economic feasibility.

\subsection{OTHER STUDIES CONCERNING TES IN THE INDUSTRIAL SECTOR}

The literature review identified a 1985 article discussing the different opportunities available for using high-temperature (i.e., $500^{\circ} \mathrm{F}$ to $1100^{\circ} \mathrm{F}$ ) TES systems (Christopher 1985). The paper focused on high-temperature sensible heat TES systems (primarily molten nitrate salt) in applications such as solar and conventional electrical power generation, industrial process heat, and waste heat recovery. It concluded that molten nitrate salt TES systems have shown economic and performance advantages over similar type systems using water/steam, oil/rock, liquid sodium, air, and other themal transfer and storage media.

The article also estimated the potential for different TES system applications related to the industrial sector (Christopher 1985): 
- For the long-term, the chemical, food, petroleum refining, and steel industries could potentially add an estimated 15,000 to $35,000 \mathrm{MW}_{\mathrm{E}}$ of cogeneration by 1990 and $50,000 \mathrm{MW}_{\mathrm{E}}$ by the year 2000 .

- The potential marketplace for high-temperature industrial process heat recovery is quite large and estimated to be more than 10 quad per year.

TES could be used to enhance operating efficiencies of some of the cogeneration systems expected to come online in the future and to aid in industrial process heat recovery. It was assumed that the TES technology used to exploit these potential application areas would be the molten nitrate salt system.

The literature review identified a paper presented in 1986 at the 21st Intersociety Energy Conversion Engineering Conference (Petri and Ong 1986). The paper primarily discusses the proposed demonstration of TES in a brick/ ceramic plant. It gives a short background on industrial energy consumption and its significance relative to total U.S. consumption. This background information is followed by an economic and technical analysis of TES in the brick/ceramic industry. The paper also discusses a demonstration project for a TES system that uses a composite phase change media. The paper concludes that applications in the brick/ceramic industry appear to offer the best firstmarket entry point and that advanced second-generation TES systems offer significant technical and economic advantages over sensible heat storage media. It ends with the comment that prototype design and testing are necessary to demonstrate operational functionality before commercialization can be expected to occur (Petri and Ong 1986).

\section{$3.5 \underline{\text { SUMMARY }}$}

In the 1970's most TES research was concentrated on the industrial sector. More recently, the residential and commercial sectors have received increased attention. At first, the typical approach for the industrial studies involved a plant audit, which then allowed an estimate to be made of the possible energy savings of installing some type of TES system. This energy savings' figure for the single site would then be projected to a national or industrywide basis, thus yielding an estimate of TES's market potential. 
This approach had a major drawback in that the economics and feasibility of a TES system depend entirely on site-specific factors; this dependence reduces the accuracy of projections made using such an approach. However, such an approach was necessary because the DOE needed national energy-saving potentials to develop a research agenda. From this literature review, it is felt that EPRI's last study done in 1984 (Melikian, McChesney and obee 1984), which discussed individual plant applications, and the paper (Petri and Ong 1986), which discussed the proposed TES demonstration in a brick/ceramic plant, indicate that future research will be more site-specific. 


\subsection{MARKET ASSESSMENTS IN THE RESIDENTIAL AND COMMERCIAL SECTORS}

In this chapter, the market assessments identified in the literature review for the residential and commercial sectors are discussed. Section 4.1 discusses the general lack of information on the market potential of TES in the residential and commercial sectors in the 1970's, and the increase in market assessment work in these sectors in the 1980's. Section 4.2 discusses what has been learned by EPRI and others in their residential/commercial TES-related research efforts from the early 1980 's to the present. Finally, Section 4.3 summarizes the work and change in attitude that have occurred in those sectors.

\subsection{THE MARKET POTENTIAL OF TES IN THE RESIDENTIAL AND COMMERCIAL SECTORS}

Information in the literature on residential and commercial heat and cool storage market assessments was limited, most likely because the direction that the DOE took after ERDA's cross-cutting study (Glenn 1976a) seemed to favor the industrial sector. The ERDA study did, however, recommend the development of TES concepts that could meet residential space heat and hot water needs. Apparently in response to this recommendation, the DOE did some work in this area, but this effort was limited and short-lived. Subsequent work in these sectors seems to have been done primarily by EPRI on the national level, and by utilities and universities on a regional level.

In the 1980's, especially 1985 and 1986, EPRI published a number of documents on the application of TES in the residential and commercial sectors. Most of the reports from the early 1980's did not comment on the market potential of TES in the sectors. This is even true of the first EPRI (1983) report, which will be discussed below. That first report was not specifically an assessment of potential but rather a more comprehensive report that covered other relevant aspects of TES. Recent reports are more direct in their assessment of TES and its potential in the residential and commercial sectors. 


\subsection{FINDINGS OF RESIDENTIAL AND COMMERCIAL MARKET ASSESSMENTS}

The following subsections discuss the findings of the individual residential and commercial market assessments located by the literature review. One subsection discusses the first major report on TES in the two sectors: the second discusses field tests by universities and utilities. A third subsection discusses the role of utilities in fostering TES, and the final subsection discusses the most recent studies located in the review.

\subsubsection{First Major TES Report on the Residential and Commercial Sectors}

In 1983 EPRI published a major report dealing exclusively with the residential and commercial sectors (EPRI 1983). Previous reports seemed to be less comprehensive and did not comment on market potential. Similarly, EPRI's 1983 study was not specifically done to assess the potential of TES in these market sectors, but to address many aspects of TES. It presents the results of the discussions among attendees of an EPRI-sponsored workshop on heat and cool storage. Possible technical and economic improvements to the various heat and cool storage technologies were discussed. Very little of the report could be termed a "market assessment," but some observations on market potential were made. Workshop observations on sensible heat materials, phase change materials, and cool storage technologies are discussed below.

\section{Observations on Sensible-Heat Materials}

The workshop concluded that strong economies of scale were associated with sensible heat TES. Small production runs were felt to be excessively expensive. For example, in the manufacturing of "storage" brick, brick manufacturers are not enthusiastic about small runs of ceramic "storage" bricks compared with large runs of regular bricks. For residential and commercial users, this situation, coupled with declining oil costs and excess utility capacity, eliminated the immediate demand for storage. It was felt there was no market for ceramic brick storage in 1983 (EPRI 1983). 


\section{Observations on Phase Change Materials (PCM)}

During the workshop, commercialization issues raised concerning PCM technologies also seemed to apply to other TES systems in general. The first major point was the recognition of the key role the utilities must play both in stimulating R\&D and in motivating commercial development by setting up timeof-day (TOD) rates that provide sufficient savings to enable the marketing of economically viable systems.

Another conclusion was that the rates have to be fixed long enough to achieve the "payback." In 1983, technology costs still were not low enough to attract customers from the heat pump, with its $2: 1$ cost advantage over conventional heating. The panel concluded that not enough was known about customer response to variable rates to design a system whose cost effectiveness depends on proper customer operation to attain electric load displacement. Neither the public nor the engineering community was ready to accept the technology, and it was felt that the first priority was continued research to develop simple workable systems that could be functionally demonstrated in the field (EPRI 1983).

\section{Observations on Cool Storage Technologies}

The group consensus on cool storage technology was that important differences exist in cool storage between the residential and commercial sectors and that currently no market exists for cool storage in the residential sector. Apparently field tests of residential systems were not successful, and current rate schedules offered no incentive for their installation. The commercial sector has more potential, primarily because space cooling in this sector accounts for $25 \%$ to $40 \%$ of the peak load of typical utilities. Even in this sector, customer types are so varied that valid generalizations are difficult (EPRI 1983). These comments on the potential application of TES in the residential and commercial sectors are much more general than corresponding comments made in the typical reports on the industrial sector.

\subsubsection{Field Tests by Universities and Utilities}

No real market assessments for the commercial and residential sectors were located in the open literature for the next couple of years. What did 
appear were papers that discussed field test results. Two studies discussed independent field tests of TES systems used for heat storage in residential space heating systems. One study (Hersh 1983), which took place in Vermont and Maine, had 45 residences equipped with electrically heated TES systems and 30 control homes that used electric baseboard heaters. The TES users were billed under a TOD rate schedule to give a price reduction on power used during off-peak periods. The study reported the following conclusions (Hersh 1983):

- Overall technical performance of the TES units was good.

- The seasonal efficiency of electricity used for space heating was the same for TES and control sites.

- At both TES and control sites, wide variations in energy consumption occurred on days having the same number of heating degree days. This suggests that site-specific effects of occupant behavior have a large impact on system performance.

- TES users were satisfied with performance.

- Barriers to rapid commercialization include high capital cost, competition from other conventional electrical heating systems, and insufficient utility incentives to encourage TES.

- Developing retrofit storage units that can be coupled to the central hydronic distribution systems in existing electricaliy heated houses would greatly increase the size of the potential TES market and directly reduce premium fuel consumption.

The study also estimated the costs to install TES for heat storage as being about $\$ 350 / \mathrm{kw}$, whereas new generating capacity is about $\$ 3500 / \mathrm{kw}$ for a nuclear power plant and $\$ 1400 / \mathrm{kw}$ for a coal-fired power plant. During the course of the Hersh study, cost of fossil fuel dropped, so TES heat storage was not as attractive as originally projected. The study identified the following reasons for the for the lack of interest in TES space heating: oil prices had declined; utilities had excess capacity to sell; and heat pumps entered the market as the low-cost heating option in milder climates (Hersh 1983). 
A paper presented at the 11th Energy Technology Conference in 1984 (Coleman 1984) discussed a study similar to the one discussed by Hersh (1983). The Coleman study involved 70 residential sites that used electric thermal storage systems for heating. Again, the conclusions echo those of the studies discussed previousiy: storage proved to be functional; its acceptance largely depends on a utility's rate structure or a benefit-sharing program; and those occupants actually using a IES system were satisfied with operating characteristics (Coleman 1984).

\subsubsection{The Role of the Utility in Fostering TES}

The literature review revealed one paper and two EPRI-sponsored reports that discussed the utilities' roles in fostering TES. The paper, presented at the 12th Energy Technology Conference, noted that the primary factors that have limited the cool storage market were related to economics (McCannon 1985). McCannon (1985) noted that a knowledgeable consumer is not likely to invest in the additional capital costs associated with TES, unless he/she is assured of economic benefit. Because customer benefits are derived only from the avoidance of demand charges and reduction of energy charges, the amount of savings will largely depend on the local utility's rate schedules. McCannon (1985) further stated that it is obvious that customer-side economics of cool storage are beyond the customer's control. It follows that because the customer-side economics are largely a function of the utility rate structure, the utilities must create an economic environment that will permit the technology to flourish.

The two EPRI-sponsored reports published in 1985 seem to indicate that the utilities recognize the validity of the observations made in McCannon's paper (1985). The reports included EPRI's first survey of commercial sector demand-side management (DSM) activities (Sloane 1985). This survey compiled information on a range of utility DSM activities directed at commercial customers; part of these efforts involved TES applications. The survey revealed several developing trends in terms of specific technologies being investigated or promoted. In general, the utility industry's interest in direct load control appeared to be waning somewhat, whereas interest in energy management systems was increasing (Sloane 1985). 
The survey results indicated that utility promotion of high-efficiency air conditioning, space heating, and water heating systems continues to be quite active. Testing or promoting commercial storage air conditioners and heat pumps for commercial applications seems to be particularly emphasized (Sloane 1985).

In the second EPRI-sponsored report, Hersh (1985) examined trends in commercial cool storage only. The study's findings support the trends observed in the survey of DSM activities. It reported that commercial cool storage installations, stimulated by utility marketing and incentive programs, have more than doubled in the past four years. The increase in installation activity is not only a result of the educational, promotional and financial programs of the utility industry, but also is related to increased reliability of TES systems and the use of appropriate high-quality refrigeration equipment. The performance of these systems has been better received by the commercial sector than have earlier systems. Hersh (1985) makes the following general conclusions :

- Many building owners who have recently installed cool storage systems have realized large cost savings. Consequently, other building owners are likely to install similar systems in the future.

- Although the scope and need for innovations and improvements still exist, most systems installed in the next ten years are expected to still be based on some combination of latent and sensible heat effects in water, with some displacement by other phase-change materials.

- Special applications, such as cooling computers and processed foods, will develop.

- Vendors will be offering turnkey systems and combined (heat/cool) storage systems.

- Ice-shucking systems and the weekly storage cycle will become more common.

\subsubsection{EPRI's Most Recent Studies}

The three most recent studies located in this literature review of the residential and commercial sectors were EPRI funded and published in 1986. 
Two of these studies actually were the first true market assessments to be reviewed (either industrial or residential/commercial) [Asbury $1986^{(a)}$ ]. The third report covers the findings of a survey of the utility industry's OSM activities aimed at the residential sector (Blevins et al. 1986). Part of this survey was focused on utility efforts to manage load. Typically load management is achieved by load control, TES, or duel-fuel heating. The assessments and survey are discussed separately below.

\section{Market Constraints for Cool Storage}

Asbury (1986) discussed market constraints for cool storage and estimated the size of utility cost savings that might be realized by using TES to shift energy use for residential space cooling to off-peak periods:

- By the end of the first decade of marketing for residential cool storage, about $\$ 154$ million would be saved, and a corresponding 958 MW reduction in non-coincident demand would occur.

- The market for cool storage equipment could range from $\$ 650$ million to nearly $\$ 3$ billion in 1984 dollars over a 10-year period.

The report also made the following estimates (Asbury 1986):

- A large potential market, about 0.5 to $1.5 \mathrm{million}$ units during the next 8 to 10 years, exists for residential cool storage equipment if a suitable financing mechanism is found.

- Early markets will be utility-specific and will be concentrated on areas that extensivelt use central air conditioning, such as the South and selected parts of the West.

- A market strategy targeting large, expensive new housing with high-quality equipment is expected to help cool storage systems gain credibility.

The results reported by Asbury (1986) present a positive outlook for the near-term application of cool storage in the residential sector. The results

(a) Also, Berstein, S., B. Hyman and R. Kunkle. July 1986 (Informal Report). Market Assessment of Heat Storage Systems in Residential and Commercial Buildings. Prepared by Energy International, Inc., for the Electric Power Research Institute, Palo Alto, California. 
in this study represent an almost complete reversal of outlook compared with the results of the EPRI workshop (EPRI 1983), discussed earlier. The 1983 EPRI study plainly stated that no market existed at that time for residential cool storage systems. It is interesting to note that in just three years the reported potential for cool storage in the residential sector had changed significantly.

It should be noted that the estimated market potential for cool storage given in the Ashbury (1986) study is not expected to be attained without utility involvement. The potential market size largely depends on the willingness of utilities to create an environment that will foster the adoption of the technology. This environment can be created through appropriate rate schedules and various benefit-sharing approaches.

\section{Market Potential For A Crushed Rock Furnace}

The last market assessment located in this literature review was another EPRI-sponsored study that examined the potential market for heat storage systems in both the residential and commercial sectors. (a) This EPRI report is not available in the open literature, but was attained through a written request to EPRI. The study had two primary objectives: 1) to assess the market potential for an EPRI-developed crushed rock furnace in the residential and commercial sectors, and 2) to develop a method that utilities could use to assess the economics of the furnace for customers.

The study estimated the annual national market potential for the crushed rock furnace in the residential sector to range from 1,000 units to 14,000 units, depending on the final initial cost of the furnace. The study reported the market potential in number of installed units for a low and high capital cost furnace, with initial cost being a function of the eventual production costs. A low-cost residential furnace was estimated to have a potential of 8,000 to 14,000 units per year, while a high-cost furnace might expect a potential of 1,000 to 3,000 units per year.

(a) Berstein, Hyman and Kunkle (1986); see footnote (a) on p. 29. 
Most of this residential market is in Northeast and North Central United States, which is also where the potential market for commercial crushed rock furnace is expected to occur. A couple of basic characteristics make the Northeast and North Central United States the primary markets for the crushed rock furnace. These areas experience both high energy costs and high heating requirements, which increases the system's cost effectiveness.

The estimated size of the conmercial market for a crushed rock furnace is greater than that of the residential market in these regions. A low initialcost furnace may place between 10,000 and 18,000 units a year, while a high initial-cost furnace may place between 2,000 and 5,000 units a year.

The report identifies the high initial cost of the crushed rock furnace as a major barrier to the technology's rapid adoption and further states that a comprehensive strategy for overcoming this and other barriers is essential if a full commercialization of the heat storage system is to take place.

Survey of the Utility Industry's DSM Activities

This survey shows that the number of storage space heating projects and reported installations had increased from 1983 to 1985 (Blevins et al. 1986). Storage air conditioning showed an increased level of activity that was accompanied by a shift from residential to commercial class customers. This lends further support to the findings of the EPRI studies published in 1985 (Hersh 1985; Sloane 1985).

Besides the increased overall level of utility activity between 1983 and 1985, the types of activity had also changed. The trend revealed by survey results shows that utilities are now conducting more promotional programs rather than test activities. This trend was evident when 1981 and 1983 activity levels were compared. Thus, the report states that reported utility activity regarding TES appears to be undergoing gradual change from testing to promotional activity (Blevins et al. 1986).

\subsection{SUMMARY}

EPRI's most recent reports seem to indicate that the future of TES in the residential and commercial sectors is much brighter than was initially 
thought. However, all of the reports place a heavy emphasis on the importance of utilities' incentives and point out that TES applications are most successful where a utility has been actively promoting or testing TES. It is unlikely that the various storage technologies will substantially penetrate the market without active utility promotion. Some sort of risk deferring or demonstration program would appear to be essential if TES is going to be accepted. 


\section{REFERENCES}

Asbury, J. G. July 1986. Market Constraints for Residential Cool Storage Systems. EPRI EM-4722, Prepared by QLA, Inc., for the Electric Power Research Institute, Palo Alto, California.

Blevins, R. P., et al. May 1986. 1985 Survey of Utility Residential End-Use Projects. EPRI EM-4578, Prepared by Plexus Research, Inc, for the Electric Power Research Institute, Palo Alto, California.

Bos, P. B., and J. F. Doyle. August 1986. Solar Thermal Central Receiver Technology Transfer Strategy Analysis, Executive Summary. Prepared by Polydyne, Inc., and Associates for Sandia National Laboratories, Livermore, California.

Boyd, D. W., et al. December 1981. Supporting Analyses for Evaluation of DOE-Funded Storage Technologies, Appendix 1. DOE/ET/600004-T2, Prepared by Decision Focus Incorporated for the U.S. Department of Energy, Washington, D.C.

Brookhaven National Laboratory. December 1982. Proceedings of the DOE Physical and Chemical Energy Storage Annual Contractors 'Review Meeting. CONF-820827, August 23-26, 1982, ArTington, Virginia. Sponsored by the U.S. Department of Energy, Washington, D.C.

Carr, J. H., P. J. Hurley and P. J. Martin. September 1978. Applications of Thermal Energy Storage to Process Heat Storage and Recovery in the Paper and Pulp Industry. CONS-5082-1, Final Report, September 1977 - May 1978. Prepared by Boeing Engineering and Construction Company for the U.S. Department of Energy, Washington, D.C.

Chemical Week. May 9, 1979. "Thermal Storage Devices are Going to Market." $57(19): 29$.

Christopher, F. N. 1985. "High Temperature Energy Storage - What Lies Ahead?" Alternative Energy Sources. 6(1):191-206.

Coleman, W. R. 1984. "Thernal Storage -- Tomorrow's Heat Today." In Proceedings of the 11th Energy Technology Conference. pp. 524-533.

Edde Howard, Inc. September 1981. Appendix to Study of Thermal Energy Storage System Information for Pulp and Paper Industry. ORNL-SUB/86X-95003/81, Prepared for the Oak Ridge National Laboratory, Oak Ridge, Tennessee.

Electric Power Research Institute (EPRI). July 1983. Opportunities in Thernial Storage R\&D. EPRI EM-3159-SR, From EPRI Workshop on Thernal Storage, Palo Alto, California, January 17, 1983, Electric Power Research Institute, Palo Alto, California. 
Glenn, D. R. February 1976a. Technical and Economic Feasibility of Thermal Energy Storage. Annual Report, C00-2558-1, General Electric Company, Philadelphia, Pennsylvania.

Glenn, D. R. October 1976b. Thermal Energy Storage Application to the Brick/Ceramic Industry. Co0-2558-2, General Electric Company, Philadelphia, Pennsylvania.

Glendenning, I. 1984. "Energy Storage." Policy and Development of Energy Resources. John Wiley \& Sons Ltd., New York, New York.

Goss, J. 0. August 1984. "Cooling Storage in Retrofit Design." In Proceedings of the 11th Energy Technology Conference.

Hersh, H. N. 1983, "Field Test and Assessment of Thermal Energy Storage for Residential Heating." CONF-831205-4, Available from the National Technical Information Service, Springfield, Illinois.

Hersh, H. N. July 1985. Current Trends in Commercial Cool Storage. EPRI EM-4125, Prepared by Argonne National Laboratory for the Electric Power Research Institute, Palo Alto, California.

Hoffman, G. H., and M. Nimmagadda. 1984. "Cool Storage Design and Operation with Time of Use Rates." In Proceedings of the 11 th Energy Technology Conference. pp. 328-347.

Institute of Gas Technology. June 1982. Thermal Energy Storage (TES) System Definition Study and Industry Characterization for the Brick, Clay, and Ceramic Industry. Chicago, Illinois.

Jaeger, F. A., et al. October 1978. Applications of Thermal Energy Storage in the Cement Industry. CoNS-5084-1, Final Report, September 1977-March 1978. Prepared by Martin Marietta Aerospace and Portland Cement Association for the U.S. Department of Energy, Washington, D.C.

Katter, L. B., and R. L. Hoskins. April 1979. Applications of Thermal Energy Storage to Process Heat and Waste Heat Recovery in the Primary Aluminum Industry. CONS/5081-1, Prepared by Rocket Research Company for the U.S. Department of Energy, Washington, D.C.

Katter, L. B., and D. J. Peterson. October 1978. Applications of Thermal Energy Storage to Process Heat and Waste Heat Recovery in the Iron and Steel Industry. CoNS/5081-1, Prepared by Rocket Research Company for the U.S. Department of Energy, Washington, D.C.

Lundberg, W. L., and J. A. Christenson. July 1979. Applications of Thermal Energy Storage to Waste Heat Recovery in the Food Processing Industry. ORNL/SUB-79/42532, Westinghouse Electric Corporation, Pittsburgh, Pennsylvania. 
Martin, J. F., M. 01 szewski and J. J. Tomlinson. October 1984, Thermal Energy Storage Technical Progress Report, April 1983 - March 1984. ORNL-TM-9170, Oak Ridge National Laboratory, Oak Ridge, Tennessee.

McCannon, L. W. 1985. "The Strong Case For Thermal Energy Storage and Utility Incentives." In Proceedings of the 12th Energy Technology Conference, Volume 12. August 1985 .

McChesney, H. R., R. W. Bass, A. M. Landerman, T. N. Obee and C. T. Sgambot1. September 1982a. Evaluation of Industrial Advanced Heat Recovery/Thermal Energy Storage Systems, Volume 1: Executive Summary. EPRI-EM-2572, Volume 1. Prepared by United Technologies Research Center for the Electric Power Research Institute, Palo Alto, California.

McChesney, H. R., R. W. Bass, A. M. Landerman, T. N. Obee and C. T. Sgamboti. December 1982b. Evaluation of Industrial Advanced Heat Recovery/Thermal Energy Storage Systems. Volume 2, EPRI-EM-2573, Prepared by United Technologies Research Center for the Electric Power Research Institute, Palo Alto, California.

Melikian, G., and H. R. Mcchesney. 1984. "Assessment of Nonlatent Heat Storage Technologies for Industrial Applications." CONF-8403146-3. Presented at the International Energy Agency Workshop on Latent Heat Stores, March 5-9, 1984, Stuttgart, FRG. Available from United Technologies Research Center, East Hartford, Connecticut.

Melikian, G., H. R. McChesney and T. N. Obee. 1984. "Identification of Thermal Energy Storage Opportunities in Industrial Processes." CONF-8403146-6, Available from the National Technical Information Service, Springfield, Illinois.

Petri, R. J., and E. T. Ong. 1986. "High Temperature Composite Thermal Energy Storage (TES) Systems For Industrial Applications." In Proceedings of the 21st Intersociety Energy Conversion Engineering Conference, Volume 2.

Pospisil, R. March 7, 1983. "Advanced Energy Technologies Near Commercialization." Energy User News. 8(10):2 \& 10.

Semler, T. T., E. J. Hansen and S. L. Richlen. February 1981. Final Report: Potential Industrial Applications for Direct Contact waste Heat Recuperation Systems. EGG-CS-5328, EG\&G Idaho, Inc, Idaho Falls, Idaho.

Sloane, B. D. July 1985. Survey of Commercial Sector Demand-Side Management Activities. EPRI EM-4142, Prepared by Synergic Resources Corporation for the Electric Power Research Institute, Palo Alto, California.

Smith, W. W., and D. D. Huxtable. April 1979. "Industrial Waste Heat For Community Application." In Energy Technology VI, Achievements in Perspective. Proceedings of the Sixth Energy Technology Conference, february 26-28, 1979, in Washington, D.C. Published by Government Institutes, Inc. 
TRW. March 1979. Thermal Energy Storage Application Areas. Prepared by TRW for the U.S. Department of Energy, Division of Energy Storage Systems, Washington, D.C.

U.S. Department of Energy (DOE). December 1982. Proceedings of the DOE Physical and Chemical Energy Storage Annual Contractors' Review Meeting. CONF-820827, August 23-26, 1982, Arlington, Virginia. Available from the U.S. Department of Energy, Washington, D.C.

Wood, R. J., D. T. Baldwin, P. N. O'Callaghan and S. D. Probert. 1983. "A Survey of the Industrial Potential for Thermal Energy Storage Systems." In Proceedings of the 2nd BHRA Fluid Engineering International Conference on Energy Storage. Presented May 24-26, Stratford-Upon-Avon, England. 
APPENDIX

ANNOTATED BIBLIOGRAPHY 


\section{ANNOTATED BIBLIOGRAPHY}

Asbury, J. G. July 1986. Market Constraints for Residential Cool Storage Systems. EPRI EM-04722, Prepared by QLA, Inc,, for the Electric Power Research Institute, Palo Al to, Calfornia.

This EPRI report estimates the cost savings that utilities might realize by using TES cool storage for residential off-peak space cooling. Cost and performance goals for cool storage equipment and an estimate of the minimum size for the residential cool storage market are presented. The results of the report are as follows:

- Over a 10-year period a market ranging from $\$ 650$ million to nearly $\$ 3$ billion (1984\$) for cool storage equipment is possible.

- The $\$ 650$ million, which represents a market of 327,000 units, could cut noncoincident demand by $958 \mathrm{MW}$ and could save the surveyed electric utilities and their customers over $\$ 150$ million in 1993. 
Berstein, S, B. Hyman and R. Kunkle. July 1986 (Informal Report). Market Assessment of Heat Storage Systems in Residential and Commercial Bui Tdings. Prepared by Energy International, Inc., for the Electric Power Research Institute, Palo Alto, California.

This report discusses the market potential of crushed rock and other heat storage systems, in particular a crushed rock furnace, in residential and small commercial buildings. For a residential crushed rock furnace with a low injtial cost, the annual national market potential was estimated to be from 8,000 and 14,000 units, whereas the potential for a more expensive furnace was estimated to be from 1,000 and 3,000 units. (High and low costs represent the estimated range of crushed rock furnace costs when in production). Most of the residential market for the product is located in the Northeast and North Central regions of the United States.

The potential market for a commercial crushed rock furnace is much larger than the residential system: 10,000 to 18,000 units annualiy for a low-cost furnace and 2,000 to 5,000 units annually for a high-cost furnace. Most of this potential market is also located in the Northeast and North Central regions, primarily because of high energy costs and high heating requirements, which increase the cost effectiveness of the crushed rock furnace. This report does not give any estimate for energy cost savings, and because the technology would only be used to move demand off peak, no overall energy consumption savings would be realized. 
Blevins, R. P., et al. May 1986. 1985 Survey of Utility Residential End-Use Projects. EPRI EM-4578, Prepared by Plexus Research, Inc., for the Electric Power Research Institute, Palo Alto, California.

This report provides information on newly implemented residential end-use projects and updated information on existing projects. The information was obtained through a survey that identified 892 residential end-use projects sponsored by 333 utilities and involved almost 6 million customer installations. The data indicate the utilities' interest continues to increase in all end-use categories except solar heating and cooling. The number of dualfuel and heat storage systems has more than doubled since 1983. 
Bos, P. B. and J. F. Doyle. August 1986. Solar Thermal Central Receiver Technology Transfer Strategy Analysis, Executive Summary. Prepared by Polydyne, Inc., and Associates for Sandia National Laboratories, Livermore, Calfornia.

This report analyzes a technology transfer strategy for solar thermal central receiver technologies. The information is not of direct use to this literature review but may be useful in designing new or analyzing existing technology transfer plans for TES technologies. 
Boyd, D. W., et al. December 1981. Supporting Analyses for Evaluation of DOE-Funded Storage Technologies, Appendix 1. DOE/ET/600004-T2, Prepared by Decision Focus Incorporated for the U.S. Department of Energy, Washington, D.C.

This report analyzes the impacts of DOE programs involving ten energy storage technologies. The purpose of the comparisons was to provide analytical results and insights as background for assessing the value of each program. This document could be usefut if, at some point in time, the current energy storage programs funded by DOE were to be compared. 
Carr, J. H., P. J. Hurley and P. J. Martin. September 1978. Applications of Thermal Energy Storage to Process Heat Storage and Recovery in the Paper and Pulp Industry, CoNS-5082-1, Final Report, September 1977 - May 1978. Prepared by Boeing Engineering and Construction Company for the U.S. Department of Energy, Washington, D.C.

This report discusses an analysis of potential TES applications in the paper and pulp industry. The primary TES application analyzed was the use of TES with waste fuel/"hog fuel" boilers to displace steam production from fossil fuel-fired boilers. Data from specific mills were analyzed, and various TES system concepts were developed and evaluated. Steam accumulators (both constant and variable pressure types) were found to be the most attractive storage concepts for this application.

A math model was developed and used to analyze the performance of the TES concepts. Results indicate potential substitution of waste wood fuel for 100,000 bbl of oil per year per installation. An industry survey revealed that potential TES applications might be able to deliver a near-term (1980's) fuel savings of about $3.2 \times 10^{6}$ bbl oil/year. This industrywide figure was developed by extrapolating estimated savings that resulted from a detailed analysis of a single mill in Longview, Washington. The TES system hardware design concepts had an estimated installed cost of $\$ 560,000$ per installation and an after-tax return on investment of over $30 \%$. The technology needed for creating a functional TES unit existed at the time of the study and was expected to be implemented industrywide in less than 3 years. 
Chemical Week. May 9, 1979. "Thermal Storage Devices are Going to Market." 57(19):29.

This journal article discusses a product developed by Dow Chemical, with the aid of a DOE contract, to store solar energy or reclaim heat from commercial and industrial processes. 
Christopher, F. N. 1985. "High Temperature Energy Storage - What Lies Ahead?" Alternative Energy Sources. 6(1):191-206.

This article discusses the different opportunities for using hightemperature (i.e., $500^{\circ} \mathrm{F}$ to $1100^{\circ} \mathrm{F}$ ) TES systems. High-temperature TES applications for renewable energies, specifically the solar thermal technologies, are discussed first. Secondly, applications are discussed for nonsolar utility peaking plants, cogeneration, industrial process heat, and heat recovery.

The article did not include energy-savings' figures for TES applications for solar thermal technologies. Applying TES to a standard utility generation plant for peaking purposes saves no energy but would increase the plant's effectiveness through better use of existing baseload capacity. On applying TES to cogeneration units, the article did not give energy-saving figures but did state that for conventional electrical generation, typically only $30 \%$ to $35 \%$ efficient, a cogeneration plant can supply electricity and steam with an overall efficiency of $70 \%$ to $80 \%$. Applying TES to industrial process heat (IPH) recovery generally reduces the cost of the reclaimed process energy. The potential marketplace for high-temperature IPH is large, but reliability and operational issues must be addressed before TES could be expected to be widely adopted.

Applying TES to industrial waste heat for recovery is the last potential market discussed in this article. Technology similar to that used in IPH recovery would be used in waste heat recovery. The potential benefits from waste heat recovery go beyond fuel savings and include pollution abatement, improved product, reduced costs of maintenance and production labor, and reduced size of required equipment. However, energy savings or the extent of potential benefits were not estimated. 
Coleman, W. R. 1984. "Thermal Storage -- Tommorrow's Heat Today." In Proceedings of the 11th Energy Technology Conference. pp. 524-533.

In this paper, electric thermal storage (ETS) and time-of-day rates in the residential sector are discussed. The paper reports on a field evaluation of ETS technologies by the American Electric Power (AEP) Service Corporation. Only residential sites were evaluated because it was felt that if the concept was proven beneficial for this market segment, it would also be suitable for commercial/industrial customer applications. This assumption has proven to be correct because ETS space heating and hot water load management systems are being promoted for residential, commercial, and industrial use.

In the evaluation, 70 residential structures were equipped with ETS systems and data logging equipment to record operating characteristics of the ETS systems. No actual figures were given for energy consumption or energy cost savings. At the end of the field tests, the residents were surveyed to evaluate customer satisfaction. Both the objective and subjective survey results were favorable. The following summarizes the paper's conclusions:

- ETS has been determined to be a viable load management concept within the AEP system.

- ETS acceptance will be directly linked to favorable ETS rate structures.

- ETS equipment is available that will provide reliable service and long life.

- Customers like ETS operating comfort and economy of operation.

- Mass application and acceptance of ETS by AEP customers will provide meaningful utllity and customer benefits by delaying and/or eliminating the need for future capacity additions.

- ETS can play a significant role in helping to balance utility load profiles and to improve system load factors. 
Edde Howard, Inc. September 1981. Appendix to Study of Thermal Energy Storage System Information for Pulp and Paper Industry. ORNL-SUB/86X-95003/81, Prepared for Oak Ridge National Laboratory, Oak Ridge, Tennessee.

This report discusses an anonymous mill site. No general introduction was provided to explain the reason for conducting the analysis. However, because it is an appendix to another document, that information most likely is in the main document. 
Electric Power Research Institute. JuTy 1983. Opportunities in Thermal Storage R\&D. EPRI EM-3159-SR, Proceedings of an EPRI Workshop on Thermal Storage, Palo Alto, California, January 17, 1983, Electric Power Research Institute, Palo Alto, California.

These proceedings summarize the findings from 36 papers presented at an EPRI-sponsored workshop on heat and cool storage. Possible technical and economic improvements were discussed for applying TES for electric load management in the residential and commercial sectors. TES systems using heat storage and cool storage also were discussed. Heat storage systems were broken down into those using sensible-heat materials versus those using phase-change materials. Cool storage systems were broken down into icemaking systems versus advanced concepts. Comparison of cool versus heat storage was very limited; however, the general conclusion was that the attractive payoffs appear in the residential sector for heat storage and in the commercial sector for cooling applications. Another general conclusion was that no "best" systems exist because site-specific characteristics are very important to the performance of a TES system. 
Glenn, D. R. February 1976a. Technical and Economic Feasibility of Thermal Energy Storage. Annual Report, C00-2558-1, General Electric Company, Philadelphia, Pennsylvania.

This report contains the results of the first major cross-cutting study of the economic and technical feasibility of TES. This study contributed to the overall ERDA objective which was to develop and disseminate TES technology for widespread national use through the following specific assessments:

- analysis of energy usage throughout the residential, commercial and industrial sectors

- analysis of energy distribution by end use within the residential, commercial and industrial sectors

- summary of the technology status of TES-related research and development

- definition of barriers and economic considerations in implementing TES.

- recognition and synthesis of TES applications.

These analyses were undertaken using a current energy scenario (i.e., current use, supply, demand and price in 1976) and a future energy scenario (i.e.. predicted use, supply, demand, and price for the early 1980 's). The results were then used to identify attractive candidate applications for TES systems.

The review of residential and industrial energy use was focused on fluctuating usage patterns, a key characteristic if TES is going to be used. Residential heat loads were studied relative to dally and seasonal demand variations occurring at the regional level. Industrial processes heavily dependent on heat supplies and/or demands were reviewed, particularly the large energy-intensive industries whose energy consumption comprises a major portion of the end product's value.

The information on barriers to using or adopting TES in each of the three sectors helps explain the subsequent focusing of government-funded research in the industrial rather than residential or commercial sectors. The report stated that the barriers in the residential and commercial markets are as basic as the general dislike of any kind of change. It was stated that these 
markets, being nonaggregated and extremely first-cost sensitive, could be expected to be sluggish in accepting TES as a substitute for more conventional systems. On the other hand, the industrial sector is less concerned with the initial outlay of capital because it tends to understand and appreciate lifecycle costing. The industrial sector has a stronger set of motivational factors or incentives for adopting and using TES than do the other sectors. Because industry is the first energy consumer impacted by a change in the energy scenario, this group has positive motivations towards realizing any economically favorable change in energy-use patterns. 
Glenn, D. R. October 1976b. Thermal Energy Storage Application to the Brick/Ceramic Industry. C00-2558-2, General Electric Company, Philadelphia, Pennsylvania.

This study was funded by the Energy Research and Development Administration (ERDA) as a direct extension of an earlier project that studied the technical and economic feasibility of TES in the residential, commercial and industrial sectors. That project identified the brick/ceramic industry as a potential consumer of TES technology.

This report was organized in three primary sections. The first section deals with an assessment of energy use within the SIC-32 industry--brick/ceramic industry. This assessment was used to help determine if the potential for energy conservation in the industry warranted additional analysis. The second section concerns the development of theoretical designs for TES systems. The last section discusses the industry's commercialization potential.

The overall study results suggest that TES application may save up to $25 \%$ of the total energy currently used by periodic kilns in the industry, equaling $16 \times 10^{12} \mathrm{Btu} /$ year. Other results were that payback periods will be from 3 to 5 years, depending on regional fuel prices, and that plant managers are favorably disposed to possible implementation because of the relative ease of integrating a TES unit into the existing plant designs. Most importantly, a first-generation rock pebble bed concept was identified that could use existing technology and equipment. 
Glendenning, I. 1984. "Energy Storage." In Policy and Development of Energy Resources. John Wiley \& Sons Ltd., New York, New York.

This article discusses the "big picture" for a few possible energy storage technologies and their applications. The specific technologies discussed are pumped hydro storage, compressed air storage, batteries, hydrogen, flywheels, thermal energy storage, and heat pumps. These technologies were felt to have the greatest potential impact and therefore are the most likely to be developed commercially in the near- to mid-term.

The information on TES in particular is very relevant to this report in that it sites previous work that compiled candidates for TES and makes two important observations:

- Often processes have not been analyzed either for their sultability for TES or for the consequent conservation potential.

- The technical task varies considerably from process to process, for example, high and low temperatures, short and long storage times, and different charge and discharge rates and durations. 
Goss, J. 0. August 1984. "Cooling Storage in Retrofit Design." In Proceeedings of the 11th Energy Technology Conference. pp. 534-541.

This paper discusses the experiences of a firm that has designed and installed several cool storage units as retrofits to existing cooling systems. The firm suggests that by using a storage unit, the "chiller" capacity could remain the same even if its cooling load increased (i.e., added square footage). No figures on energy cost savings or energy consumption savings were given. 
Hersh, H. N. 1983. "Field Test and Assessment of Thermal Energy Storage for Residential Heating." CoNF-831205-4, Available from the National Technical Information Service, Springfield, Illinols.

This paper discusses the findings of a TES field test conducted over two heating seasons in Vermont and Maine. In the test 45 residences used TES, and 30 control homes used electric baseboard heaters. The TES users were billed under applicable time-of-day rates. Electrical and thermal measurements were taken from all sites. This study revealed the following:

- Overall technical performance of the IES units was good.

- The seasonal efficiency of electricity use was the same for TES and control sites.

- At both TES and control sites, wide variations in energy consumption occurred on days having the same number of heating degree days.

- The TES users were satisfied with performance.

- Barriers to rapid commercialization include high capital cost, competition from other electrical heating systems (nonstorage) and insufficient utility investment to encourage TES.

- Developing retrofit storage units that can be coupled to the central hydronic distribution systems in existing fuel-heated houses would greatly increase the size of the potential TES market and directly reduce prenium fuel consumption.

The possible energy cost savings or energy consumption savings were not estimated, but the report did state that TES installed costs are about $\$ 350 / \mathbf{k W}$, whereas new generating capacity is about $\$ 3500 / \mathrm{kW}$ for nuclear and $\$ 1400 / \mathrm{kW}$ for coal. 
Hersh, H. N. July 1985. Current Trends in Commercial Cool Storage. EPRI EM-4125, Prepared by Argonne National Laboratory for the Electric Power Research Institute, Palo Alto, California.

This report describes cool storage systems recently installed in commercia] buildings and evaluates current trends in cool storage. The following findings were reported:

- Use of off-peak cooling is increasing, and the states with the most new projects are California, Illinois, and Texas.

- Utiltties are playing a major role in the tncreased use of off-peak cooling, mainly through various financial incentives and special commercial rate schedules.

- Storage air conditioning is said to perform well and to provide a satisfactory alternative to conventional air conditioning systems for commercial buildings. However, performance verification is needed.

- Although there are twice as many ice installations as chilled water systems, the chilled water systems have $30 \%$ more cooling capacity.

- Ice systems are usually installed in smaller bulldings.

- Operating strategies are being more finely tured to the details of the utility rate structure than in the past.

- Ice-shucking systems, which allow ice building to be decoupled from ice storage, are being considered for operation on a weekly cycle to take advantage of weekend off-peak rates.

- While some systems have been monitored for energy use, engineering data at the subsystem level are lacking.

- Storage cooling bills are substantially lower than bills for conventional systems.

- Quantitative economic data on total system costs are not generally available.

- Storage systems are being increasingly designed to provide both heating and cooling. 
It is concluded that the use of cool storage is spreading. Also, the technical and cost performance of cool storage technology, plus most aspects of energy and utility economics in some utility areas, weigh heavily against the use of conventional nonstorage cooling systems in commercial buildings. 
Hoffman, G. H., and M. Nimmagadda, 1984. "Cool Storage Design and Operation with Time of Use Rates." In Proceedings of the 11th Energy Technology

Conference. pp. 328-347.

This article discusses what the electric utilities are currently doing to foster the acceptance of cool-storage-assisted air conditioning. The article also suggests additional steps that utilities could take to encourage architects and engineers to use this promising technology. The article did not include estimates of potential energy or cost savings or reasons why this technology should be adopted. 
Institute of Gas Technology. June 1982. Thermal Energy Storage (TES) System Definition Study and Industry Characterization for the Brick, Clay, and Ceramic Industry. Institute of Gas Technology, Chicago, Illinois.

This report discusses the operating characteristics of several plants in the brick, clay, ceramic, and refractory industries. It estimates potential national fuel savings if TES systems were developed and installed in these industrial plants. An economic analysis of an industrial-sized TES system was conducted to determine the potential level of industry acceptance. Much of the basis for this report was the result of previous work done for the DOE and showed the following:

- Implementing the so-called first-generation TES systems can reduce the fossil-fuel energy consumption of the brick and refractories industries by about 45\%, which will have a significant national impact.

- TES systems provide an acceptable return on investment with investment paybacks ranging from 2 to 4 years, depending on local energy costs.

- First-generation TES systems can be integrated with current plant processing methods and equipment using conventional engineering practices and materials. Second-generation systems (latent heat storage) should be developed through an R\&D program.

The report estimated potential fuel savings resulting from applying TES nationally as $42.7 \times 10^{12}$ Btu/yr by 1980 (assuming that full implementation had occurred by 1980). 
Jaeger, F. A., et al. October 1978. Applications of Thermal Energy Storage in the Cement Industry. CONS-5084-1, Final Report, September 1977 - May 1978. Prepared by Martin Marietta Aerospace and Portland Cement Association for the U.S. Department of Energy, Washington, D.C.

This report assesses the cement industry for the potential application of TES in reclajming rejected process heat. Four plants representing the typical types of U.S. plants were analyzed in detail. In the analysis, sources of rejected energy and possible uses of this energy were identified. The report estimated that by using TES with waste heat electric power generation units, about $4 \times 10^{6}$ barrels of oil could be saved annually. The return on investments varied considerably depending on kiln type.

The following sections discuss the study's specific conclusions concerning sources of waste heat, uses for waste heat, storage system selection, system size and performance, and economic analysis.

Sources of Waste Heat

The dry process kilns were determined to be the only practical sources of waste heat as opposed to the wet process kilns, whose lost energy is at too low a temperature to be of major use within the plant. Of the types of dry process kilns, the long dry kilns have the highest quality and quantity of recoverable energy, followed by the single-stage suspension preheater and the four-stage suspension preheater. Of the sources of waste heat in each plant, the kiln exit gas was by far the best source; it contains $80 \%$ of the waste heat and is the plant's highest temperature source. The clinker cooler exhaust gas was also found to be a practical source of heat when used in conjunction with the kiln exit gas system. The heat in each of these sources is concentrated and easily recoverable.

Uses for Waste Heat

The use of the kiln exit gas and clinker cooler gas to generate electricity for the cement plant was found to be the most cost-effective method considered. 


\section{Storage System Selection}

A rockbed-type storage system was found to be the most economical type of storage. This system could use granite, cement clinker or limestone as the storage medium. A system using molten salt as the storage medium was the next best type of storage and is recommended for large plants if technical problems develop with a rockbed system.

\section{System Size and Performance}

System size and performance were determined for both types of storage systems using the four typical plant models. The size of the equipment was within that normally fabricated for other uses, and the performance was able to easily meet the requirements of the plant operation. No problems were encountered in physically locating and installing the system in any of the plants. The system could be installed with only a few days or weeks of halted production.

\section{Economic Analysis}

Generating electricity using waste heat is economically attractive for long-dry and single-stage preheater kilns. Assuming an $11 \%$ escalation rate in the cost of electricity, a $15 \%$ after tax cost of capital and a $25 \mathrm{mil} / \mathrm{kWh}$ of electricity, the return on investment (ROI) is $44 \%$ for the long-dry kiln (Plant 1 ) and $31 \%$ for the single-stage preheater $k i$ in (Plant 3 ). When rockbed thermal storage is used, the ROI increases to $50 \%$ for Plant 1 . The ROI for the rockbed storage/power system is $30 \%$ for Plant 3. The analysis of Plant 2 (0.9 MWe) shows that for small power generation rates, thermal storage is not desirable if the required power during kiln shut down can be purchased on short notice. 
Katter, L. B., and R. L. Hoskins. April 1979. Applications of Thermal Energy Storage to Process Heat and Waste Heat Recovery in the Primary Aluminum Industry. CONS/5081-1, Prepared by Rocket Research Company for the U.S. Department of Energy, Washington, D.C.

This report discusses the results of an analysis of the aluminum industry for potential applications of TES. To obtain the information, the entire industry was surveyed and a detailed analysis was conducted of an aluminum plant in Ferndale, Washington. The analysis resulted in an application of TES that could be used by the surrounding community rather than by just the plant. The potential source of waste energy used in this case was the large amount of low-grade heat in the primary gas stream of the pollution control system that could be used for heating nearby communities.

The estimated fuel savings for the specific site was about $1.37 \times 10^{12}$ Btu/year. Extrapolating this figure on an industrywide basis resulted in an estimated 6.5 million barrels/year of fuel displacement. 
Katter, L. B., and D. J. Peterson. October 1978. Applications of Thermal Energy Storage to Process Heat and Waste Heat Recovery in the Iron and Steel Industry. CONS/5081-1, Prepared by Rocket Research Company for the U.S. Department of Energy, Washington, D.C.

This report presents the results and conclusions of an analysis of the iron and steel industry for potential applications of TES for waste heat recovery. The project's scope was limited to currently available technology in order to increase the likelihood of industrywide adoption by 1985 .

Based on the analysis of various energy streams in the 8ethlehem Steel plant in Seattle, the primary fume gas collected from the electric arc steel remelting furnaces was determined to be the optimum energy source for the detailed analysis. A conceptual waste energy collection system was designed in which high-temperature $\left(\sim 1,300^{\circ} \mathrm{F}\right)$ energy was collected and stored in a bed of solid material as sensible energy. This energy would be used to generate steam that would drive a turbogenerator to produce electricity for peak power shaving. If such a system were applied to all U.S. electric arc furnaces, a projected savings of $1.9 \times 10^{6}$ barrels of fuel oil per year was estimated to be achievable by 1985, assuming that an intensive implementation program was started when the report was completed. 
Lundberg, W. L. and J. A. Christenson. July 1979. Applications of Thermal Energy Storage to Waste Heat Recovery in the Food Processing Industry. ORNL/SUB-79/42532, Westinghouse ETectric Corporation, Pittsburgh, Pennsylvania.

This report discusses the assessment of waste heat sources and uses at two food processing plants: H. J. Heinz Pittsburgh factory and the Heinz Lake City factory. The Pittsburgh factory would use hot waste water for TES, whereas the Lake city factory would use waste heat from refrigeration. The report also discusses the subsequent development and evaluation of conceptual waste heat recovery systems.

This study indicated that a system to extract thermal energy from hot waste water could be used to heat fresh water in quantities large enough to reduce the Pittsburgh factory's input fuel usage by $7 \%$ to $8 \%$, and the investment required would return at the rate of $34 \%$ annually. The study also indicated that a system to extract heat from the waste heat of the Lake city plant's refrigeration system could be implemented and that the reclaimed heat could be used to heat both fresh water and air. The factory's natural gas usage would be reduced by as much as 23\%, and the annual return on investment for the air and water heating system would be about $7 \%$.

Based upon the study's results and other data, the study stated that it is obvious that waste heat is available in the food industry 1) at temperatures which enable recovery with conventional equipment and 2) in quantities that could cause the displacement of fossil fuels in significant amounts. Industrywide, the implementation of systems similar to those conceptualized for these two plants would recover an estimated $6.4 \times 10^{12}$ Btu from waste heat. This is roughly equivalent to $.7 \%$ of the annual consumption of the entire Food and Kindred Products Industry--SIC 20. 
Martin, J. F., M. 01szewski and J. J. Toml inson. October 1984. Thermal Energy Storage Technical Progress Report, April 1983 -March 1984. ORNL-TM-9170, 0ak Ridge National Laboratory, Oak Ridge, Tennessee.

This document discusses the development of TES technology under the Oak Ridge National Laboratory (ORNL) TES Program from Apri] 1983 to March 1984. The program goals and project structure are presented. Each TES research area for building heating and cooling and industrial applications is discussed, and the year's progress is presented. A summary of technology transfer to the private sector is included. This document offers primarily technical rather than market information. 
MCCannon, L. W. 1985. "The Strong Case for Thermal Energy Storage and Utility Incentives." In Proceedings of the 12th Energy Technology Conference. Volume 12. August 1985.

This paper is basically promottonal literature explaining the merits of cool storage and stressing the importance of the utility's role as a change agent. The author comments on the changing environment that utilities face, such as the reversal of the slowing growth in electrical demand and the increased regulation and costs of nuclear plant construction. The author feels that the utility industry will be compelled to give more thought to alternative methods of generation and to new technologies such as cool storage, which are viable alternatives to new generating capacity. The author concludes that the utilities should be offering rate structures and other forms of incentives to those who would install some form of cool storage system and states:

"The financial inducements which will be required for the next few years can be looked upon as "seed money" necessary to get the technology moving. In time, the technology may continue to expand on its own momentum. At that stage, utilities will gain the equivalent of new generating capacity with little or no capital investment." 
McChesney, H. R., R. W. Bass, A. M. Landerman, T. N. Obee and C. T. Sgamboti. 1982a. Evaluation of Industrial Advanced Heat Recovery/Thermal Energy Storage Systems Volume 1: Executive Sumnary. EPRI-EM-2572, Volume 1, Prepared by United Technologies Research Center for the Electric Power Research Institute, Palo Alto, California.

McChesney, H. R., R. W. Bass, A. M. Landerman, T. N. Obee and C. T. Sgamboti. 1982b. Evaluation of Industrial Advanced Heat Recovery/Thermal Energy Storage Systems. Volume 2, EPRI-EM-2573, Prepared by United Technologies Research Center for the Electric Power Research Institute, Palo Alto, California.

These reports describe the findings of an EPRI-sponsored study. Volume 1 summarizes the work performed and results achieved. Volume 2 contains detailed industrial process data, pertinent technical and cost information on equipment, proposed plant system designs for advanced heat recovery (AHR)/TES, and a complete discussion of the procedures used and results obtained. The objectives of this study were as follows:

- to identify industrial applications where TES can be used to enhance the recovery and use of waste heat

- to review and compile data on availability, performance, and cost of thermal storage and other industrial energy management equipment to be installed and operated in 1985

- to determine if retrofitting AHR systems that use TES would be economically and institutionally viable for both the industrial plant and its supplying utility

- to develop the interest of potential industrial users in systems described above.

The information gathered in the study was the result of detailed assessments of 24 candidate AHR/TES plant applications, of these, 14 waste heat recovery applications in 11 industries were found to have return on investments of at least $20 \%$. Besides these plant assessments, installation and equipment costs and investment payback periods were estimated. It was found that 9 of the 14 systems would require some form of TES to maximize their economic and energy savings. The economic recovery $(220 \%)$ of waste heat to generate process heat or electrical power was estimated to have the potential to displace fossil fuels equivalent to $66 \times 10^{6} \mathrm{bbl}$ of oil/year. 
Melikian, G., and H. R. McChesney, 1984. "Assessment of Nonlatent Heat Storage Technologies for Industrial Applications." CONF-8403146-3, Presented at the International Energy Agency Workshop on Latent Heat Stores, March 5-9, 1984, Stuttgart, FGR. Available from United Technologies Research Center, East Hartford, Connecticut.

In this study, 17 industries were examined and onsite visits were made to 14 plants. In a preliminary evaluation of the plant data obtained during these visits, 24 candidate AHR/TES applications were identified, each involving the possible use of TES with heat exchangers, heat pumps and waste-heat-driven Rankine-cycle power generation systems. The 12 industrial plants in which the 24 possible applications were found are listed below:

- natural gas processing

- fluid milk

- canned specialties

- textile

- petroleum refining

- alumina (inorganic chem)

- glass containers

- iron and steel

- motor vehicle parts
- meatpacking

- canned specialties

- malt beverages

- paper and pulp

- alkali and chlorine

- synthetic rubber

- cement, hydraulic

- farm machinery

- aerospace equipment.

The study's findings indicate that large quantities of waste heat are available from industrial plants across the United States. Also, for selected applications, fuel energy savings can be enhanced and optimized using TES systems with equipment currently on the market. The results also indicate that the varfability in industrial sites requires decisions about TES to be made on a site-by-site basis. Waste heat boilers producing process steam from hightemperature gases and liquid/liquid heat exchangers for heating industrial fluids appear to offer the greatest potential for waste heat recovery. Rankine cycle power generation systems and electric-drive heat pumps appear to possess a more limited potential. Results indicated that if TES were implemented throughout a utility's service area, the aggregate effect could be very beneficial to the utility. Results also indicate that sensible rather than latent TES systems will probably be the more cost-effective method of waste heat recovery. 
Melikian, G., H. R. McChesney and T. N. Obee. 1984. "Identification of Thermal Energy Storage Opportunities in Industrial Processes." CONF-8403146-6, Presented at the International Energy Agency Workshop on Latent Heat Stores, March 5-9, 1984, Suttgart, FGR. Available from the National Technical Information Services, Springfield, Illinois.

This EPRI paper provides a detailed evaluation of TES opportunities in various industrial processes. The study was an extension of an ongoing EPRIfunded program to assist member utilities in identifying and evaluating industrial process energy conservation and management (EC\&M) opportunities for their member utilities. The actual work involved plant audits in 22 different industries selected by 7 participating utilities. The audits revealed 33 potential TES applications that required different EC\&M designs, which were developed and economically ranked. The industries that had the 33 potential applications fall into 23 types:
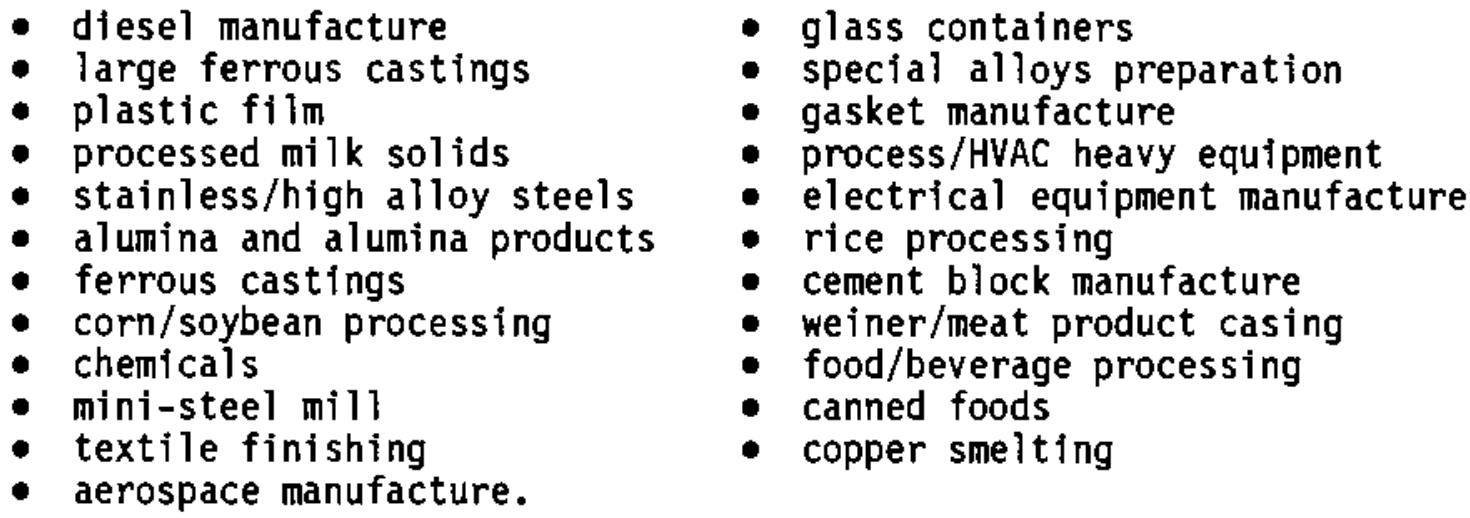

This study found that of several generic technologies (heat exchangers, waste heat boiler, Rankin cycle, heat pump closed/open cycle, TES, GT/elect gen/chiller) the heat exchanger is an economically attractive selection, especially for combustion air preheating. The remaining technologies become attractive in applications where the simple heat exchanger is excluded for reasons other than economics (i.e., mismatch of supply availability at time of demand).

The paper concludes that significant opportunities exist for TES in industrial plants. The assessment also revealed that feasible TES opportunities require one or more of the following conditions to be present: a) source/sink variability, b) high frequency (charged/discharge) cycle utilization; and c) cost savings other than energy savings from the industrial process. 
Petri, R. J., and E. T. Ong. 1986. "High Temperature Composite Thermal Energy Storage (TES) Systems for Industrial Applications." In Proceedings of the 21st Intersociety Energy Conversion Engineering Conference, volume 2.

This paper describes the significance of industrial energy consumption relative to this country's total energy consumption. This is followed by a short discussion of the evolution of government-funded studies on TES applications in industrial processes. Finally, an economic and technical feasibility of TES in the brick/ceramic industry is provided. The paper concludes the following:

- Several applications exist in the industrial sector where TES allows reject heat to be used within the industrial process to displace purchased energy.

- A specific application in the brick/ceramic industry appears to offer the best first-market entry point.

- Advanced second generation composite latent/sensible TES media offer significant mass, volume, and performance benefits over sensible heat media.

- Modeling of thermal energy storage waste heat systems based on CompPhase media confirms the potential for $33 \%$ brick/ceramic plant energy consumpticn savings ( $\$ 1000$ per day) and $<1.0$ year paybacks.

- Further CompPhase media development is required to thermally tailor PCM melting points to bed stratification temperatures.

- Prototype design, scale-up and field testing is needed before the technology can be comnercialized. 
Pospisi] R. March 7, 1983. "Advanced Energy Technologies Near Comnercialization." Energy User News. 8(10):2 \& 10 .

This short journal article discusses a few energy technologies that might be ready for commercialization in 5 to 10 years. No estimates of potential energy savings are provided. 
Semler, T. T., E. J. Hansen and S. L. Richlen. February 1981. Final Report: Potential Industrial Applications for Direct Contact Waste Heat Recuperation Systems. EGG-CS-5328, EG\&G Idaho, Inc., Idaho FalTs, Idaho.

This report gives the results of a study done on the potential for industrial applications of direct-contact waste heat recuperator systems. This potential was examined in the major energy-consuming industries (except for the petroleum and chemical industries). A detailed economic analysis of four specific applications with waste heat streams ranging from $175^{\circ} \mathrm{F}$ to $750^{\circ} \mathrm{F}$ is discussed. One of the four systems analyzed failed to show significant economic promise. The report concluded that a waste heat stream between $400^{\circ} \mathrm{F}$ and $750^{\circ} \mathrm{F}$ and having more than $10,000 \mathrm{cfm}$ is most economically promising for direct contact waste heat recuperation and hot process water delivery. 
Sloane, B. D. July 1985. Survey of Commercial Sector Demand-Side Management Activities. EPRI EM-4142, Prepared by Synergic Resources Corporation for the Electric Power Research Institute, Palo Alto, California.

This report identifies and summarizes commercial sector demand-side management (DSM) activities and programs that the surveyed utilities were currently sponsoring. Selected utilities were surveyed through questionnaries and telephone contacts to collect information on programs dealing with HVAC, lighting, water heating, and refrigeration technologies or with commercial energy audit and customer assistance activities.

of particular interest to this report are the trends identified in commercial DSM technology; those trends showed increasing interest in storage air conditioning and heat pumps, and waning interest in direct load control. 
Smith, W. W., and D. D. Huxtable. April 1979. "Industrial Waste Heat For Community Application." In Energy Technology VI, Achievements in Perspective. Proceedings of the Sixth Energy Technology Conference, February 26-28, 1979, in Washington, D.C. Published by Government Institutes, Inc.

This paper discusses the results of a regional in-plant survey of 150 major industrial plants in the Pacific Northwest. From the survey, a data base containing regional energy consumption and waste heat characteristics was compiled. The paper concluded that because of the relatively low median temperature of the region's industrial waste heat, the potential for energy conservation is significantly greater and economically more attractive when industrial waste heat is used directly (i.e., district heating) rather than used for electrical power generation. The paper goes on to present an argument for establishing district heating thermal grid networks using industrial waste heat as the primary energy source to serve nearby communities. The paper concludes with the following paragraph:

"The technical plant data presented herein pertains directly to the Pacifi: Northwest and may vary by regional industrial mix. However, significant deviation on a national scale from the median waste heat temperature of $280^{\circ} \mathrm{F}$ is not expected unless large concentrations of steel mills are present. Relatively few industrial plants reject a significant quantity of high temperature waste heat, and increased conservation efforts by industry will continue to reduce the high temperature energy losses. It is therefore concluded that mid to low temperature energy will be the major source of industrial reject heat in the future, and utilization of this energy within surrounding communities via district heat themal grid networks can result in significant energy savings and conservation at economically competitive rates." 
TRW. March 1979. Thermal Energy Storage Application Areas. Prepared by TRW for the U.S. Department of Energy, Division of Energy Storage Systems, Washington, D.C.

This study covers seasonal storage for building heating and cooling, thermal storage for industrial waste and process heat recovery, thermal storage for solar-thermal power generation, daily and short-term storage for building heating and cooling, and thermal storage for electric utility load management. To determine TES potential in industrial waste and process heat recovery, five industries were undergoing more detailed process analysis: food processing, aluminum, cement, paper and pulp, and iron and steel.

Preliminary figures for possible annual energy savings for these industries were given as about 12 million barrels of oil by 1985. Applying TES to solarthermal power generation was estimated to offer a potential annual savings of 175 million barrels of oil by 2000, if an active development and commercialization program were undertaken. Daily and short-term storage for building heating and cooling was expected to provide an annual oil savings from TES applications of 15 M80E by 1985 and $230 \mathrm{MBOE}$ by 2000 . For TES applications in electric utility load management, cost saving estimates rather than estimates of displaced fuel consumption were given: $\$ 50$ to $\$ 250 \mathrm{million}$ per year were expected in residential and commercial buildings. 
U.S. Department of Energy. December 1982. Proceedings of the DOE Physical and Chemical Energy Storage Annual Contractors' Review Meeting. CONF-820827, Conference, August 23-26, 1982, Arlington, Vírginia. Available from the U.S. Department of Energy, Washington, D.C.

These proceedings of the DOE's physical and chemical energy storage contractor's review meeting in 1982 included the projects within Oak Ridge National Laboratory's TES Program that concern building heating and cooling and industrial applications. The section on TES for building heating and cooling and industry has 19 short articles on various findings and on-going work.

One of the articles, entitled "Identify Generic Thermal Energy Storage Needs for Industrial Applications," discusses an indepth review of the 6 studie's commissioned by ERDA/DOE to evaluate thermal storage applications in the brick/ refractory, cement, iron and steel, food, pulp-paper, and aluminum industries. It also has as its scope a review of any other relevant TES applications analysis that have been reported in the literature since the original 6 were published. This report had no information on any other analysis other than the six major industry studies mentioned above. 
Wood, R. J., D. T. Baldwin, P. W. O'Callaghan and S. D. Probert. 1983. "A Survey of the Industrial Potential for Thermal Energy Storage Systems." In Proceedings of the 2nd BHRA Fluid Engineering International Conference on Energy Storage. Presented May 24-26, Stratford-Upon-Avon, England.

This article reports a survey of British industry for opportunities to conserve energy through the application of storage cascades. The survey found that the technical and economic potential of storage cascades represents about $1 \%$ of the total energy use (130 MTCE/yr or about 3.6 quad) in the manufacturing sector of the British economy. Therefore, the potential energy consumption savings from applying energy storage technologies are approximately .036 quad. Even in the areas where the .036 quad could be saved by storage technology, more conventional waste heat recovery methods may be an economically superior option.

The information for this article was collected using two questionnaires. The first was initially circulated to 502 British companies covering 147 thermally activated processes. The second questionnaire was sent to 2746 companies. The overall response to the survey was $7.6 \%$, with the useful response representing $5 \%$ of those questionnaires issued. Large users of thermal energy, such as the iron and steel industry, were not covered by the survey because of the difficulty of obtaining a meaningful response to the questionnaire. 


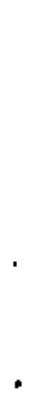


PNL-6457

UC-94e

\section{DISTRIBUTION}

No. of

Copies

OFFSITE

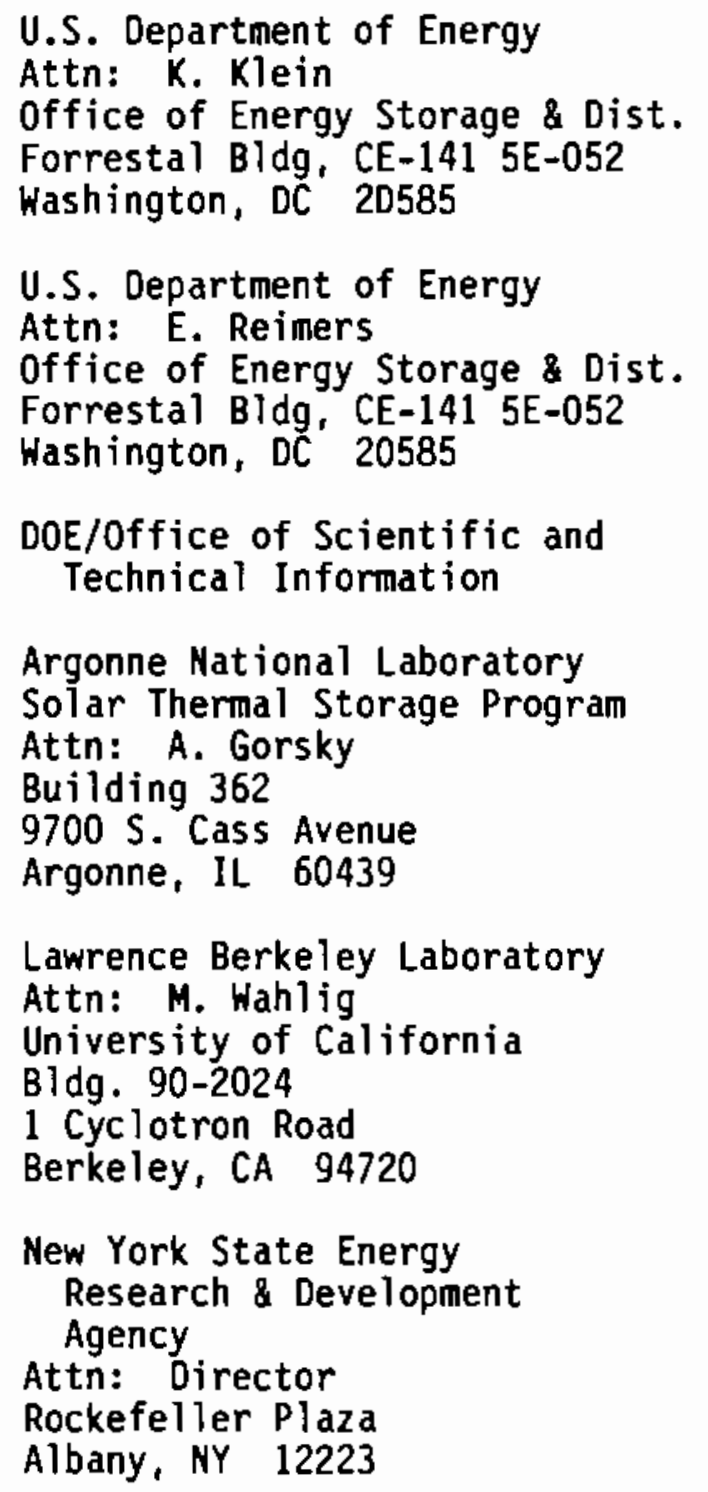

No, of

Copies

New York State Energy

Research \& Development Agency

Attn: G. Walmet

Rockefeller Plaza

Albany, NY 12223

Oak Ridge National Laboratory

Attn: M. Taylor

PO Box $X$

Oak Ridge, TN 37830

Oak Ridge National Laboratory

Attn: J. Tomlinson

PO Box $X$

Oak Ridge, TN 37830

Office of Congressman

Sid Morrison

Attn: Kevin Billings,

Legislative Asst.

1330 Longworth B1dg.

Washington, DC 20515

Solar Energy Research Institute

Attn: B. Gupta

1536 Cole Blvd

Golden, Co 80401

University of Alabama

Attn: E. Brett

School of Mines and Energy Development

Box 6282

University, AL 35486

University of Alabama

Attn: W. Schaetzle

School of Mines and Energy Development

Box 6282

University, AL 35486 
No. of

Copies

No. of

Copies

US Department of Interior

Attn: Natural Resources

Library

Serials Branch (G/E)

Washington, DC 20240

\section{FOREIGN}

Bengt Hidemark Gosta Danielson Arkitekter SAR

Attn: A. Boysen

Jarntorget 78

S-11 29 Stockholm

Sweden

Commission of European

Communities

Attn: P. Zegers

$D G X I I, E 3$

200 Weststraat

Brussels, Belgium

Heidemij Adviesbureau

Attn: A. Snijders

P0 Box 264

NL-6800 AG Arnhem

The Netherlands

I.E.N.E.R.

EPF-Ecublens

Attn: B. Saugy

1015 Lausanne

Switzerland

KFA Julich

Projekt leitung Energieforschung

Attn: F. J. Friedrich

PO Box 1913

D-5170 Julich

West Germany
KFA Julich, PLE

Attn: $V$. Lottner

P0 Box 1913

D-5170 Julich

West Germany

Laboratory for Energetics

Attn: B. Qvale

Technical University of Denmark

OK-2800 Lyngby

Denmark

Management Office for Energy Research PEO

Attn: K. Joon

P. 0. Box 8242

NL-Utrecht

The Netherlands

B. Mathey

Consulting-Engineers Ltd.

2205 Montezilion-Neuchatel

Switzerland

Ministry of Trade and Industry

Attn: P. Vainio

Energy Department

POHJ Makasunikatu 6

SF-00130 Helsinki 13

Finland

Public Works of Canada

Attn: E. L. Morofsky

C456 Sir Charles Tupper Bldg.

Riverside $\mathrm{Or}$. and Heron Rd.

Ottawa, Ontario

K1A 0M2 Canada

Riso National Laboratory

Attn: P. L. Christensen

DK-4000 Roskilde

Denmark

Swedish Council for Building

Research

Attn: S-E. Lundin

St. Goransgatan 66

S-112 33 Stockholm

Sweden 
No. of

Copies

Swedish Council for Building Research

Attn: W. Raldow

St. Goransgatan 66

S-112 33 Stockholm

Sweden

Swiss Federal Energy Office

Attn: A. Fehr

$\mathrm{CH}-3003$ Berne

Switzerland
No. of

Copies

ONSITE

DOE Richland Operations Office

J. J. Sutey

40 Pacific Northwest Laboratory

R. C. Adams

J. M. Bates

D. R. Brown

J. A. Dirks

M. K. Drost

M. P. Hattrup (12)

C. H. Imhoff

L. D. Kannberg (10)

G. E. Spanner

R. O. Weijo (3)

T. A. Williams

Technical Report Files (5)

Publishing Coordination (2) 
